\title{
DEVONIAN-CARBONIFEROUS MAGMATISM AND METALLOGENY IN THE SOUTH URAL ACCRETIONARY-COLLISIONAL SYSTEM
}

\section{A.M. Kosarev $\oplus^{1 \bowtie}$, A.G. Vladimirov $\oplus^{2,3}$, A.I. Khanchuk ${ }^{4}$, D.N. Salikhov ${ }^{1}{ }^{1}$, V.B. Kholodnov ${ }^{5}$, T.A. Osipova ${ }^{5}$, G.A. Kallistov ${ }^{5}$, I.B. Seravkin ${ }^{1}$, I.R. Rakhimov ${ }^{1}{ }^{1}$, G.T. Shafigullina $\oplus^{1}$}

\author{
${ }^{1}$ Institute of Geology, Ufa Federal Research Centre of the Russian Academy of Sciences, 16/2 Karl Marx St, Ufa 450077, \\ Republic of Bashkortostan, Russia \\ ${ }^{2}$ Sobolev Institute of Geology and Mineralogy, Siberian Branch of the Russian Academy of Sciences, 3 Academician \\ Koptyug Ave, Novosibirsk 630090, Russia \\ ${ }^{3}$ Tomsk State University, 36 Lenin Ave, Tomsk 634050, Russia \\ ${ }^{4}$ Far East Geological Institute, Far East Branch of the Russian Academy of Sciences, 159 Prospect 100-letiya, Vladivostok \\ 690022, Russia \\ ${ }^{5}$ Zavaritsky Institute of Geology and Geochemistry, Ural Branch of the Russian Academy of Sciences, 15 Academician \\ Vonsovsky St, Ekaterinburg 620016, Russia
}

ABSTRACT. The oceanic stage in the history of the South Urals completed in the Ordovician - Early Silurian. The Ordovician through Devonian events in the region included the formation of an island arc in the East Ural zone from the Middle Ordovician to Silurian; westward motion of the subduction zone in the Late Silurian - Early Devonian and the origin of a trench along the Main Ural Fault and the Uraltau Uplift; volcanic eruptions and intrusions in the Magnitogorsk island arc system in the Devonian. The Middle-Late Paleozoic geodynamic evolution of uralides and altaides consisted in successive alternation of subduction and collisional settings at the continent-ocean transition. The greatest portion of volcanism in the major Magnitogorsk zone was associated with subduction and correlated in age and patterns of massive sulfide mineralization (VMS) with Early - Middle Devonian ore-forming events in Rudny Altai. Within-plate volcanism at the onset of volcanic cycles records the Early $\left(D_{1} e_{2}\right)$ and Middle $\left(\mathrm{D}_{2} \mathrm{ef}_{2}\right)$ Devonian slab break off. The volcanic cycles produced, respectively, the Buribay and Upper Tanalyk complexes with VMS mineralization in the Late Emsian; the Karamalytash complex and its age equivalents in the Late Eifelian - Early Givetian, as well as the lower Ulutau Formation in the Givetian. Slab break off in the Late Devonian - Early Carboniferous obstructed the Magnitogorsk island arc and supported asthenospheric diapirism. A new subduction zone dipping westward and the Aleksandrovka island arc formed in the Late Devonian - Early Carboniferous. The Early Carboniferous collision and another event of obstructed subduction led to a transform margin setting corresponding to postcollisional relative sliding of plates that produced another slab tear. Postcollisional magmatism appears as alkaline gabbro-granitic intrusives with related rich Ti-magnetite mineralization $\left(\mathrm{C}_{1}\right)$. Transform faulting persisted in the Middle Carboniferous through Permian, when the continent of Eurasia completed its consolidation. The respective metallogenic events included formation of $\mathrm{Cu}-\mathrm{Ni}$ picritic dolerites $\left(\mathrm{C}_{2-3}\right)$, as well as large-scale gold and Mo-W deposits in granites $\left(\mathrm{P}_{1-2}\right)$.

KEYWORDS: plate tectonics; plume tectonics; subduction; transform boundary; collision settings; island arc; magmatism; metallogeny; mineral deposit; Urals; Altai

FUNDING: The study was supported by grants 12-05-31470, 14-05- 00747, 14-05-00712, and 14-05-20269-g from the Russian Foundation for Basic Research and grant 15-17-10010 from the Russian Science Foundation. It was carried out as part of several projects: ONZ-9.3, 27P of the Geoscience Department of the Russian Academy of Sciences; joint projects of the Siberian, Ural, and Far East Branches of the Russian Academy of Sciences and the Ufa Federal Research Centre (project 12-S-5-1022, IP 77 Magmatism, Metamorphism, and Mineral Potential of Altaides and Uralides and project 79 Magmatism and Metallogeny at Transform Plate Boundaries: Causes of Diversity and Evolution in Space and Time); Programs for Performance Progress of Tomsk and Bashkirian Universities. The work was performed within the program of the state task of the IG UFRC RAS (project 0246-2019-0078) and the state task of the IGG UB RAS (project AAAA-A18-118052590029-6).

\section{RESEARCH ARTICLE}

Received: August 11, 2020

Correspondence: Alexander M. Kosarev, amkosarev@mail.ru

FOR CITATION: Kosarev A.M., Vladimirov A.G., Khanchuk A.I., Salikhov D.N., Kholodnov V.B., Osipova T.A., Kallistov G.A., Seravkin I.B., Rakhimov I.R., Shafigullina G.T., 2021. Devonian-Carboniferous magmatism and metallogeny in the South Ural accretionary-collisional system. Geodynamics \& Tectonophysics 12 (2), 365-391. doi:10.5800/GT-2021-12-2-0529 


\title{
ДЕВОН-КАМЕННОУГОЛЬНЫЙ МАГМАТИЗМ И ОРУДЕНЕНИЕ ЮЖНО-УРАЛЬСКОЙ АККРЕЦИОННО-КОЛЛИЗИОННОЙ СИСТЕМЫ
}

\author{
А.М. Косарев ${ }^{1}$, А.Г. Владимиров ${ }^{2,3}$, А.И. Ханчук ${ }^{4}$, Д.Н. Салихов ${ }^{1}$, В.В. Холоднов ${ }^{5}$, Т.А. Осипова ${ }^{5}$, \\ Г.А. Каллистов ${ }^{5}$, И.Б. Серавкин ${ }^{1}$, И.Р. Рахимов ${ }^{1}$, Г.Т. Шафигуллина ${ }^{1}$
}

\author{
${ }^{1}$ Институт геологии УФИЦ РАН, 450077, Уфа, ул. Карла Маркса, 16/2, Республика Башкортостан, Россия \\ ${ }^{2}$ Институт геологии и минералогии им. В.С. Соболева СО РАН, 630090, Новосибирск, пр-т Академика Коптюга, \\ 3, Россия \\ ${ }^{3}$ Томский государственный университет, 634050 Томск, пр-т Ленина, 36, Россия \\ ${ }^{4}$ Дальневосточный геологический институт ДВО РАН, 690022, Владивосток, пр-т 100-летия Владивостока, \\ 159 , Россия \\ ${ }^{5}$ Институт геологии и геохимии им. А.Н. Заварицкого УрО РАН, 620016, Екатеринбург, ул. Академика Вонсовского, \\ 15 , Россия
}

АНнотАЦИЯ. Завершение океанической стадии на Южном Урале произошло в ордовик - раннесилурийское время. В среднем ордовике в Восточно-Уральской зоне начала формироваться среднеордовикско-силурийская островная дуга. В позднем силуре - раннем девоне произошел перескок зоны субдукции на запад, формирование глубоководного желоба в зоне Главного Уральского разлома - Уралтауского антиклинория и началось образование вулкано-интрузивных формаций Магнитогорской островодужной системы $\left(\mathrm{D}_{1}-\mathrm{D}_{3}\right)$. В среднепозднепалеозойской геодинамической эволюции уралид и алтаид произошло последовательное чередование субдукционных и трансформно-коллизионных обстановок в зоне перехода континент - океан. На Южном Урале с субдукционной обстановкой связан главный объем вулканических ассоциаций Магнитогорской мегазоны. В раннем $\left(\mathrm{D}_{1} \mathrm{e}_{2}\right)$ и среднем $\left(\mathrm{D}_{2} \mathrm{ef}_{2}\right)$ девоне произошли разрывы слэба, фиксирующиеся проявлениями внутриплитного вулканизма, приуроченного к начальным этапам раннедевонского позднеэмсского и позднеэйфельско-раннеживетского колчеданоносных вулканических циклов. В позднем девоне - раннем карбоне произошла блокировка Магнитогорской островной дуги с разрывом слэба, и, как следствие, - главный этап астеносферного диапиризма. На рубеже позднего девона - раннего карбона сформировалась новая зона субдукции западного падения и возникла Александровская редуцированная островная дуга. Раннекаменноугольная коллизия и повторная блокировка субдукционной зоны привели к трансформной обстановке, отвечавшей постколлизионному скольжению литосферных плит, и вновь - к появлению астеносферного окна («slab-tear»). В этой обстановке были сформированы габбро-гранитные интрузивы повышенной щелочности и связанные с ними Ti-Mgt месторождения мирового класса $\left(\mathrm{C}_{1}\right)$. Трансформная геодинамическая обстановка оставалась ведущей на протяжении среднего карбона - перми, когда произошла окончательная консолидация Евразийского континента.

КЛЮЧЕВЫЕ СЛОВА: плейт-тектоника, плюм-тектоника, субдукция, трансформная граница, коллизионная обстановка, островная дуга, магматизм, металлогения, рудные месторождения, Урал, Алтай

ФИНАНСИРОВАНИЕ: Работа поддержана грантами 12-05-31470, 14-05-00747, 14-05-00712, 14-05-20269-г РФФИ и грантом 15-17-10010 РНФ. Выполнялась в рамках нескольких проектов: ОНЗ-9.3, 27 Г Геолого-геофизического отдела РАН; совместных проектов Сибирского, Уральского и Дальневосточного отделений РАН и Уфимского федерального исслдовательского центра (проект 12-C-5-1022, ИП 77 «Магматизм, метаморфизм и минеральный потенциал Алтаидов и Уралид» и проекта 79 «Магматизм и металлогения на границах трансформируемых плит: причины разнообразия и эволюции в пространстве и времени»); Программы успеваемости Томского и Башкирского университетов. Работа выполнена в рамках программы государственного задания ИГ УФИЦ РАН (проект 0246-2019-0078) и государственного задания ИГ УрО РАН (проект АААА-А18-118052590029-6).

\section{INTRODUCTION}

The Ural-Mongolia-Tien Shan orogenic belt is of special interest for geoscientists being the largest transcontinental structure of Central Asia which comprises uralides and altaides produced by the major Uralian and Altai orogenies [Berzin et al., 1994; Şengör et al., 1993; Puchkov, 2003, 2010]. Most of controversy in the history of uralides and altaides concerns plume tectonics [Dobretsov et al., 2010] and its denied or overestimated role as the main cause of magmatism and related abundant magmatic, hydrothermal, and epithermal mineralization. Meanwhile, most models overlook the contribution of mantle diapirism which is the post-subduction response of the asthenosphere to plate collisions and/or sliding past one another [Davies, von Blanckenburg, 1995; Khain et al., 1996; Tychkov, Vladimirov, 1997]. Reliable seismic tomographic evidence of asthenospheric slab tears is available for Cenozoic orogens (Pacific coasts of both Americas and eastern Eurasia, etc.), where mantle magmatism has particular chemical and isotopic signatures [Martynov, Khanchuk, 2013; Vladimirov et al., 
2020]. The provinces of pre-Cenozoic magmatism, such as the Ural-Mongolia-Tien Shan orogen, likewise accommodate unusual igneous rocks that formed in poorly understood tectonic settings not yet interpreted in terms of plate tectonics or plume activity. This study aims at bridging this gap by suggesting evolution scenarios for the South Ural accretionary-collisional system and identifying geodynamic factors responsible for the extremely rich volcanic massive sulfide (VMS) and associated $\mathrm{Fe}, \mathrm{Cu}-\mathrm{Pb}-\mathrm{Zn}, \mathrm{Au}, \mathrm{Ti}-\mathrm{Mgt}$, and $\mathrm{Cu}-\mathrm{Ni}$ mineralization.

\section{TECTONICS AND METALLOGENY OF SOUTH URALS}

The South Ural province covers an area of $500 \times 500 \mathrm{~km}$ between the East European craton in the west and the Turgay trough in the east. Previous studies have revealed the KrakaSakmar, Magnitogorsk, East-Ural, and Aleksandrovka-Denisovka paleovolcanic belts [Seravkin et al., 1992; Sopko, 1969; Perfil'iev, 1979; Peive et al., 1977; Romanov, 1985; Puchkov, Ivanov, 1985; Puchkov, 1993, 2010]. The problems of the relationship between metallogeny and the deep structure of the Southern Urals are discussed in numerous published works [Golovanova, 2005; Anan'eva et al., 1996; Kondiajn, 2011; Seravkin et al., 2001; Rilkov et al., 2013; Puchkov, 2010; Seravkin, 2010; Kontar', Libarova, 1997; Zoloev et al., 2001; Berlyand, 2007]. A great achievement of deep geology in the Urals was the identification of volcanic belts with oceanic, island-arc and continental types of deep sections, as well as the elucidation of lateral variations in the thickness of the "granite" and "basalt" layers and the layer of the crust-mantle mixture [Berlyand, 1982, 2007; Seravkin, Tsvetkova, 1982], which correlate with the types and volumes of mineralization. The special place occupies research V.V. Maslennikov [Maslennikov, 1999], which result in a detailed study of the lithology and mineralogy of volcanogenic-sedimentary rocks and processes of low-temperature metamorphism of massive sulfide in the volcanic structures, to draw conclusions about the proximity of processes of forming a modern and ancient massive sulfide deposits.

The tectonic map of the South Urals (Fig. 1) shows additionally the Valerianovka and Borovskoe subzones of the Kostanay basin and the Ubagan uplift within the Central Turgay belt in order to provide more details on the eastern margin of the Ural orogen [Teterev, 1971; Abdullin, 1984].

The major Magnitogorsk zone comprises several smaller structures: Main Ural Fault or Voznesenka-Sakmar, West Magnitogorsk, Central Magnitogorsk, and East Magnitogorsk zones (Fig. 2). In the Main Ural Fault zone chromite deposits, and in the Magnitogorsk zone VMS deposits of the world-class, as well as numerous gold deposits and unique iron deposits are located [Seravkin, 2010; Fershtater, 2013]. Reliable correlations (Fig. 3) and geodynamic reconstructions are possible due to biostratigraphic constraints from conodonts for the western and eastern margins of the Magnitogorsk zone [Prokin et al., 1985, 1988; Maslov et al., 1993; Stratigraphic Schemes..., 1993; Seravkin, 1997, 2010; Seravkin et al., 1992; Puchkov, 2000, 2010; Kosarev et al., 2014;
Salikhov et al, 2014; Gas'kov, 2015], together with petrographic and geochemical studies of volcanites.

The Main Ural Fault zone in the western flank of the Magnitogorsk zone, 5 to $17 \mathrm{~km}$ wide and about $400 \mathrm{~km}$ long, consists of serpentinite mélange (see Fig. 2) with kilometers-long fragments of Ordovician-Early Silurian oceanic felsic and mafic rocks, Silurian-Devonian island arc volcanics and volcanic-sedimentary complexes, Carboniferous limestones and Carboniferous-Permian intrusives in the serpentinite matrix, which coexist with serpentinite clasts in olistostrome layers. In general, these complexes represent an accretionary wedge terrane. In the west, the VoznesenkaSakmar zone borders the Central Ural zone (Uraltau) along a fault dipping southeast at $30-60^{\circ}$. The Central Ural zone has an antiformal structure and is composed of Proterozoic, late Precambrian (Vendian) and Paleozoic rocks, with their ages constrained by isotopic and fauna data [Puchkov, 1996, 2010]. It comprises a complex of high-pressure eclogites and blueschists typical of subduction settings. The East Magnitogorsk zone of faults and serpentinite mélange in the eastern margin of the Magnitogorsk zone separates the latter from the East Ural uplift (see Fig. 1).

Oceanic volcanism. Late Precambrian (Vendian) and Paleozoic oceanic and island arc volcanics are known from the Maksyut eclogite-blueschist complex in the Central Ural zone and from the Sysert-Ilmen uplift in the South Urals where metabasalts and plagiogneisses have $\mathrm{U}-\mathrm{Pb}$ ages of $543 \pm 46$ and $590 \pm 20$ Ma [Krasnobaev et al., 1998a, 1998b; Puchkov, 2000, 2010]. Another island arc complex of Lushnikovo occurs in the southern extension of the Central Ural zone, in the Kazakhstan part of the South Urals (Ebet zone), with a U-Pb zircon age constraint of 590 Ma obtained for felsic volcanics [Samygin et al., 2007]. The Vendian Ebet island arc presumably postdated a Late Proterozoic - Early Vendian oceanic stage, which agrees with known regional geology [Puchkov, 2010].

Oceanic rifting and volcanism in South Urals culminated in Ordovician - Early Silurian time. Oceanic complexes of similar ages $\left(\mathrm{O}_{2}-\mathrm{S}_{1}\right)$ were found throughout the South Urals, including in the Sakmar, East Ural, and Trans-Ural zones [Perfil'ev, 1979; Puchkov, Ivanov, 1985; Puchkov, 1993]. Basalts in all complexes have enriched compositions similar to E-MORB [Seravkin et al., 1992], while N-MORB compositions are known from the Polakovsky complex in the Voznesenka-Sakmar zone [Semenov, 2000; Spadea et al., 2002]. All South Ural oceanic basalts show OIB-like signatures [Simonov et al., 2004].

\section{ISLAND ARC VOLCANISM}

The history of the South Urals included Ordovician Silurian and Devonian events of island arc volcanism (see Fig. 1) that produced the East Ural paleovolcanic belt (see Fig. 1) distinguished through reconstructions [Seravkin et al., 1992]. According to the materials of the "Urseis-95" seismic profile, the eastern fall of the subduction zone is assumed [Ermolaeva, 2001].

Ordovician - Silurian arc volcanics of the East Ural belt are present in the northern Emanzhelinsk district as the 


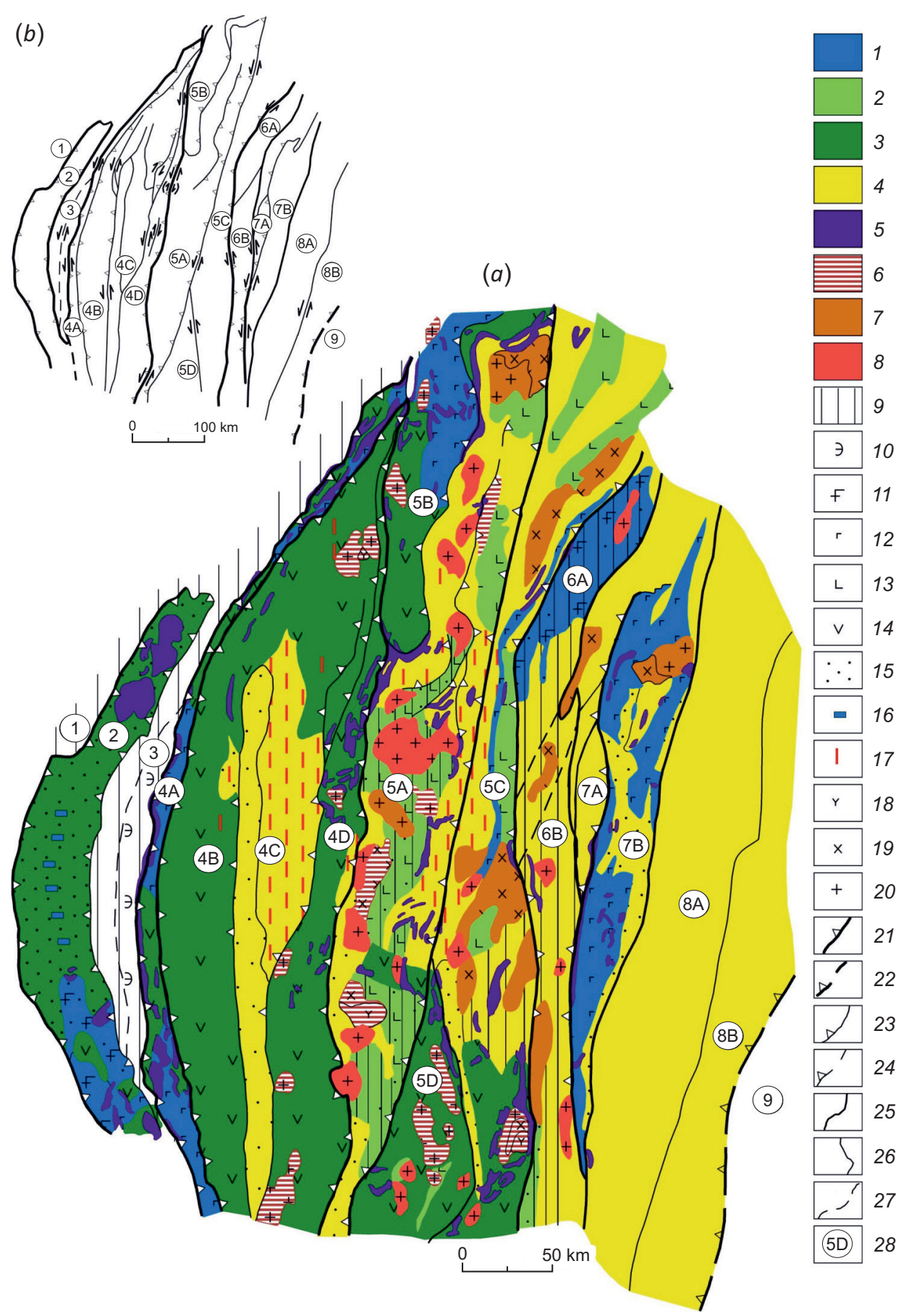

Fig. 1. Simplified geology and tectonic settings of the South Urals (a). Compiled by A.M. Kosarev after [Teterev, 1971; Abdullin, 1984; Seravkin et al., 1992; Ryazantsev et al., 2005]. (b) - a block diagram in which multidirectional arrows indicate the direction of shear discontinuities.

1-8 - volcanic and intrusive rocks of various tectonic settings: 1 - Ordovician-Silurian tholeiitic and moderate alkaline basalts of continental rifts and oceanic islands $\left(0-\mathrm{S}_{1-2}\right), 2$ - Silurian-Devonian arc basalts, basaltic andesites, and basalt-andesite-dacite-rhyolite associations; back-arc spreading basalts $\left(\mathrm{S}_{2}-\mathrm{D}_{1}\right.$ ?), 3 - Devonian arc basalts, trachybasalts, shoshonites, and basalt-rhyolite, basaltandesite-dacite-rhyolite, basalts, basaltic andesites, and trachybasalt-shoshonite-latite-rhyolite associations; back-arc and arc spreading basalts and basalt-rhyolite associations (all $\mathrm{D}_{1} \mathrm{e}-\mathrm{D}_{3} \mathrm{fm}$ ), 4 - Early Carboniferous trachybasalt-trachyandesite-dacite-rhyolite associations $\left(\mathrm{C}_{1} \mathrm{t}_{1-2}, \mathrm{C}_{1} \mathrm{t}_{2}-\mathrm{v}_{2}\right)$, volcaniclastics, and carbonate sediments $\left(\mathrm{C}_{1} \mathrm{t}_{2}-\mathrm{C}_{2}\right) ; 5-8$ - intrusive rocks: 5 - Middle-Late Devonian serpentinized peridotites, 6 - gabbro-diorite-plagiogranite complexes, 7 - Carboniferous diorite-granodiorite intrusive complexes $\left(\mathrm{C}_{1-3}\right), 8-\mathrm{Late}$ Paleozoic (Permian) granitoids $\left(\mathrm{Pz}_{3}, \mathrm{P}\right) ; 9$ - continental blocks; 10 - zones of eclogite-blueschist metamorphism; 11-15 - predominant types of volcanic and volcanic-sedimentary rocks of various settings: $€-\mathrm{O}_{2}$ continental rifting trachybasalts $(11), \mathrm{O}_{2}-\mathrm{S}_{1}$ oceanic basalts (12), $\mathrm{O}_{2}-\mathrm{S}_{1-2}$ arc basalts, basaltic andesites, andesites, and rhyodacites; $\mathrm{S}_{2}-\mathrm{D}_{1}$ ? back-arc spreading basalts $(13), \mathrm{D}_{1}-\mathrm{D}_{3}$ alkaline and subalkaline arc basalts, basaltic andesites, andesites, and rhyodacites in the Magnitogorsk zone and its surroundings (14), volcanicsedimentary, clastic-tephroid, clastic, and carbonate sedimentary rocks of different ages (15); 16 - same, with buried ancient volcanic complexes; 17 - within-plate magmatism; 18-20 - predominant types of intrusives in individual bodies and complexes: gabbro (18), 
diorites and quartz diorites (19) and granitoids (20); 21-22 - boundaries of zones and dip directions of tectonic sheets, with later thrusts and oblique reverse faults, observed in geological and seismic data (21) and inferred (22); 23-24-observed (23) and inferred (24) thrusts and oblique reverse faults; 25-27 - geological boundaries: observed boundaries of zones and subzones (25), observed boundaries of facies and complexes within zones (26), inferred boundaries (27); 28 - numbers of zones, subzones, and blocks: 1 - East European craton, Bashkirian Uplift; 2 - Kraka-Mednogorsk zone, Zilair Basin; 3 - Central Ural zone, Uraltau Uplift; 4 Magnitogorsk Basin, including Voznesenka-Sakmar zone of serpentinite mélange or Main Ural fault (4A), West Magnitogorsk zone (4B), Central Magnitogorsk zone (4C), East Magnitogorsk zone (4D); 5 - East Ural zone, including East Ural uplift (Ural granitic axis) and a fragment of East Ural trough (Yemanzhelinsk-Varna zone) in the northeastern part (5A), Aramil-Sukhtelinsky basin (5B), East Ural trough, Chelyabinsk graben, and Marinovka continental block ( $\mathrm{R}-\mathrm{Pz}_{1}$ ?) (Marinovka complex and Dzhetygara subzone) in the south (5C), Buruktal-Yelenovka block, a fragment of a Devonian mature arc (5D); 6 - Troitsk-Kengussay zone of the Trans-Ural uplift, with predominant sedimentary rocks $\mathrm{R}_{2}$ ? $-\mathrm{O}_{2}$, including Troitsk block with rift-related volcanism $\left(\mathrm{O}_{2}\right)(6 \mathrm{~A})$, Central and Southern subzones composed of continental metasedimentary rocks $\left(\mathrm{R}_{2}\right.$ ? $\left.-\mathrm{O}_{2}\right)$ with diorite $\left(\mathrm{C}_{1}\right)$ and granitic $\left(\mathrm{Pz}_{3}\right)$ intrusions $(6 \mathrm{~B}) ; 7-\mathrm{Aleksandrovka-}$ Denisovka zone $\left(\mathrm{O}-\mathrm{C}_{1}\right)$, including Aleksandrovka subzone with high-Al calc-alkaline and subalkaline basalt-andesite associations $\left(\mathrm{C}_{1}\right)$ $(7 \mathrm{~A})$, Denisovka subzone with oceanic basalts $\left(\mathrm{O}_{2}-\mathrm{S}_{1}\right.$ ?), transitional arc-collisional basalt-andesite-rhyodacite associations $\left(\mathrm{C}_{1}\right)$, and clastic-tephroid deposits ( $\mathrm{D}_{2}$ ef- $\mathrm{C}_{1}$ ) (7B); 8, 9 - Kostanay trough: Valerianovka volcanoplutonic belt (8), including Valerianovka subzone (basin) with calc-alkaline and subalkaline volcanism $\left(\mathrm{D}_{3}\right.$ ? $\left.-\mathrm{C}_{1}\right)$ and skarn magnetite deposits of the Sokolovo-Sarbay belt $(8 \mathrm{~A})$ and Borovskoe subzone (uplift) composed mainly of sediments $\left(C_{1}\right)$, with minor amounts of volcanics (8B); Ubagan uplift composed of Lower Paleozoic to Triassic schists $\left(\mathrm{Pz}_{1}\right)$, volcanics and sediments $\left(\mathrm{D}_{3}-\mathrm{C}_{1}\right)$, and ultramafics $\left(\mathrm{D}_{3}-\mathrm{C}_{1}\right)(9)$.

Рис. 1. Геолого-структурная схема Южного Урала (a). Составлена А.М. Косаревым на основе [Teterev, 1971; Abdullin, 1984; Seravkin et al., 1992; Ryazantsev et al., 2005]. (b) - структурная схема, на которой разнонаправленные стрелки указывают направление сдвиговых разрывных нарушений.

1-8 - вулканогенные и магматические формации различных геодинамических обстановок: 1 - базальтовая толеитовая и умереннощелочная формации стадии континентального рифтогенеза и океанической стадии, 2 - базальт-андезибазальтовая и базальт-андезит-дацит-риолитовая островодужные формации $\left(0-\mathrm{S}_{1-2}\right)$, базальтовая формация зон задугового спрединга $\left(\mathrm{S}_{2}-\mathrm{D}_{1}\right.$ ?), 3 - базальтовая, базальт-риолитовая, базальт-андезит-дацит-риолитовая, базальт-андезитобазальтовая, трахибазальтовая, трахибазальт-шошонит-латит-риолитовая и шошонитовая островодужные формации девонского (D $\left.\mathrm{D}_{1} \mathrm{-} \mathrm{D}_{3} \mathrm{fm}\right)$ возраста и одновозрастные базальтовые и базальт-риолитовые формации зон задугового и внутридугового спрединга, 4 - вулканогенные трахибазальт-трахиандезит-дацит-риолитовые формации $\left(\mathrm{C}_{1} \mathrm{t}_{1-2}, \mathrm{C}_{1} \mathrm{t}_{2}-\mathrm{v}_{2}\right)$, вулкано-терригенная и карбонатная осадочная формация $\left(\mathrm{C}_{1} \mathrm{t}_{2}-\mathrm{C}_{2}\right)$; 5-8 - интрузивные магматические формации и комплексы: 5 - ультрабазиты серпентинизированные, 6 - габбро-диорит-плагиогранитные комплексы среднепозднедевонского возраста, 7 - диорит-гранодиоритовые интрузивные комплексы каменноугольного возраста $\left(\mathrm{C}_{1-3}\right), 8$ - гранитоиды позднепалеозойского, пермского возраста $\left(\mathrm{Pz}_{3}, \mathrm{P}\right)$, 9 - блоки с континентальной корой, 10 - структурные зоны с эклогит-глаукофановым метаморфизмом; 11-15 - преобладающий тип вулканических и вулканогенно-осадочных пород в составе формации и формационных рядов различных геодинамических обстановок: 11 - трахибазальты стадии континентального рифтогенеза $\left(€-\mathrm{O}_{2}\right), 12$ - базальты океанической стадии $\left(\mathrm{O}_{2}-\mathrm{S}_{1}\right), 13$ - базальты, андезибазальты, андезиты, риодациты островодужной стадии $\left(\mathrm{O}_{2}-\mathrm{S}_{1-2}\right)$, базальты зон задугового спрединга $\left(\mathrm{S}_{2}-\mathrm{D}_{1}\right.$ ?), 14 - базальты, андезибазальты, андезиты, риодациты островодужные нормальной и умеренной щелочности Магнитогорской мегазоны и прилегающих участков $\left(\mathrm{D}_{1}-\mathrm{D}_{3}\right), 15$ - вулканогенно-осадочные, терригенно-тефроидные, терригенные, карбонатные осадочные породы в формациях разного возраста; 16 - то же, с перекрытыми древними вулканическими комплексами; 17 - зоны проявления внутриплитного вулканизма и магматизма; 18-20 - преобладающие типы интрузивных пород в отдельных интрузиях и интрузивных комплексах: 18 - габброиды, 19 - диориты и кварцевые диориты, 20 - гранитоиды; 21-22 - границы структурных зон с направлением падения пластин, осложненные надвиговыми и сдвигонадвиговыми разрывными нарушениями: 21 - установленные по геологическим и сейсмическим материалам, 22 - предполагаемые; 23-24 надвиговые и сдвигонадвиговые разрывные нарушения, осложняющие внутреннюю структуру зон: 23 - установленные, 24 - предполагаемые; 25-27 - геологические границы: 25 - между структурными зонами и подзонами, установленные, 26 внутри структурных зон, между фациальными типами пород и комплексами, установленные, 27 - то же, предполагаемые; 28 номера структурно-формационных зон, подзон, блоков: 1 - Восточно-Европейская платформа, Башкирский антиклинорий; 2 - Кракинско-Медногорская зона, Зилаирский синклинорий; 3 - Центрально-Уральская зона, Уралтауский антиклинорий; 4 - Магнитогорский мегасинклинорий: 4А - Вознесенско-Присакмарская зона серпентинитового меланжа (зона гуР), 4В Западно-Магнитогорская зона, 4C - Центрально-Магнитогорская зона, 4D - Восточно-Магнитогорская зона; 5 - ВосточноУральская зона: 5A - Восточно-Уральское поднятие (гранитная ось Урала), в северо-восточной части зоны - фрагмент Восточно-Уральского прогиба (Еманжелинско-Варненская зона), 5В - Арамильско-Сухтелинский синклинорий, 5С - ВосточноУральский прогиб, зона Челябинского грабена, на юге Мариновский блок с континентальной корой (R-Pz? $\mathrm{R}_{1}$ ) (Maриновский комплекс и Джетыгаринская подзона), 5D - Бурыктальско-Еленовский блок - фрагмент девонской островной дуги на континентальном основании; 6 - Троицко-Кенгуссайская зона Зауральского поднятия с преобладанием осадочных пород $\mathrm{R}_{2}$ ?-О, $6 \mathrm{~A}$ - Троицкий блок с проявлением вулканизма $\left(\mathrm{O}_{2}\right)$ стадии континентального рифтогенеза, 6В - Центральная и Южная подзоны, сложенные метаосадочными отложениями $\mathrm{R}_{2}$ ?- $\mathrm{O}_{2}$ континентального типа с интрузиями диоритов $\mathrm{C}_{1}$ и гранитоидов $\mathrm{Pz}_{3} ; 7$ - Александровско-Денисовская зона $\left(\mathrm{O}-\mathrm{C}_{1}\right)$ : 7А - Александровская подзона с проявлением базальт-андезитовой известково-щелочной и субщелочной высокоглиноземистой серии $\left(\mathrm{C}_{1}\right), 7 \mathrm{~B}$ - Денисовская подзона с проявлением океанического базальтового вулканизма $\left(\mathrm{O}_{2}-\mathrm{S}_{1}\right.$ ?) и переходного островодужно-коллизионного базальт-андезит-риодацитового вулканизма $\left(\mathrm{C}_{1}\right)$ и терригенно-тефроидных отложений $\left(\mathrm{D}_{2} \mathrm{ef}-\mathrm{C}_{1}\right) ; 8-9-$ Кустанайский прогиб: 8 - Валерьяновский вулканоплутонический пояс: $8 \mathrm{~A}$ - Валерьяновская подзона (синклинорий) с вулканизмом известково-щелочной и субщелочной серии $\left(\mathrm{D}_{3}\right.$ ?- $\left.\mathrm{C}_{1}\right)$, со скарново-магнетитовыми месторождениями Соколово-Сарбайского пояса, 8В - Боровская подзона (антиклинорий) с вулканитами $\mathrm{C}_{1}$ небольшого объема и преобладающими осадочными толщами; 9 - Убоганское поднятие, сложенное отложениями от нижнего палеозоя до триаса, присутствуют кристаллические сланцы $\left(\mathrm{Pz}_{1}\right)$, вулканогенные и осадочные породы $\mathrm{D}_{3}-\mathrm{C}_{1}$, ультрабазиты $\mathrm{D}_{3}-\mathrm{C}_{1}$. 


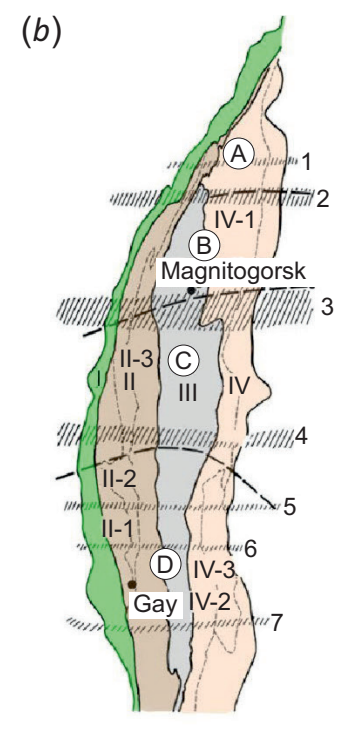

$(a)$

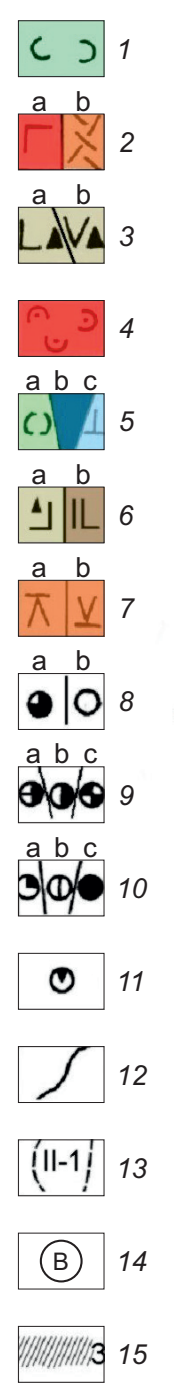

(B)

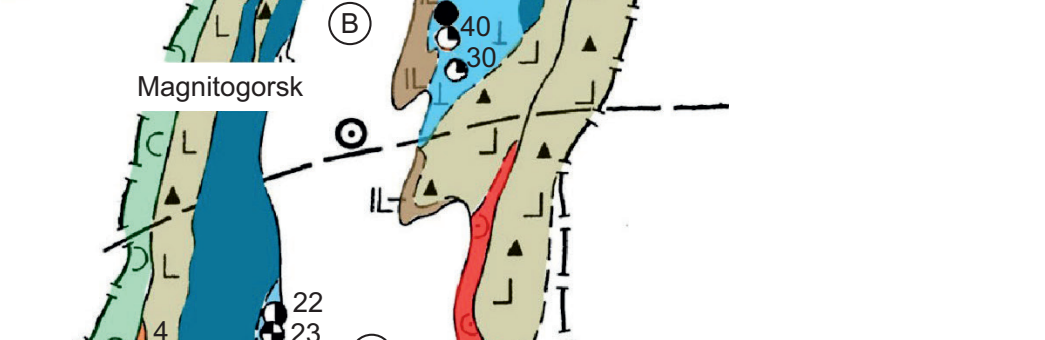

(C)
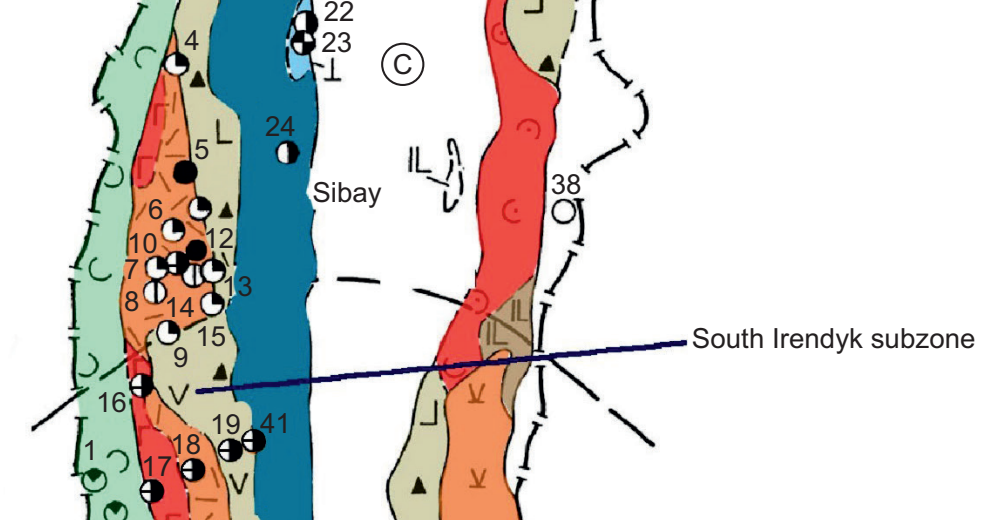

(D)
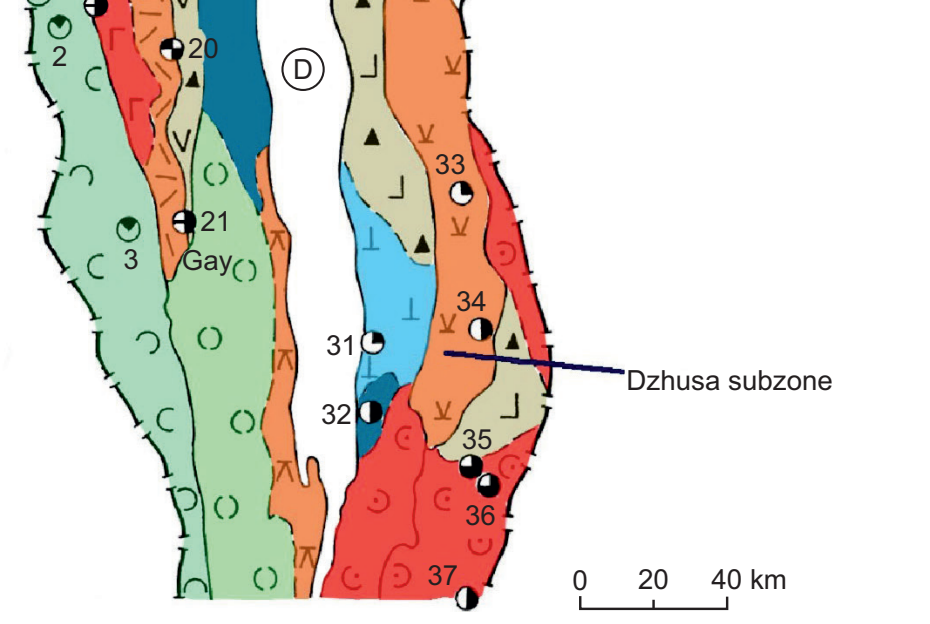

Fig. 2. Igneous complexes and related VMS mineralization in the Magnitogorsk zone, complemented after [Seravkin, 2007] with additions by A.M. Kosarev.

Igneous complexes: 1 - basalts $\left(\mathrm{O}-\mathrm{S}_{1}\right) ; 2$ - contrasting (a) and continuous (b) basalt-rhyolite $\left(\mathrm{D}_{1} \mathrm{e}_{2}\right)$ complexes; 3 - basaltic andesites $\left(\mathrm{D}_{2} \mathrm{ef}_{1}\right)$ : basalt-basaltic andesite $(\mathrm{a})$ and mixed basalt-andesite-rhyolite (b) complexes; 4 - basalts $\left(\mathrm{D}_{1} \mathrm{e}\right) ; 5$ - basalt-rhyolite $\left(\mathrm{D}_{2}\right.$ ef $\left.{ }_{2}\right)$ : basaltic (a), contrasting (b), and continuous (c) complexes; 6 - basaltic andesites $\left(D_{2}\right)(a), K-N a$ basalts and basaltic andesites $\left(D_{3}\right)(b)$; 7 - Yusinsk $\left(D_{2}\right)(a)$ and $\left(D_{2} e_{1}\right)$ Dzhusa (b) basalt-andesite-rhyolite complexes. Massive sulfide deposits (VMS) with related base metal mineralization of different compositions: 8 - copper (Dombarovsky type) (a), zinc (Filizchay type) (b); 9 - zinc-copper Cu>Zn (a), copper-zinc, $\mathrm{Cu}<\mathrm{Zn}$ (b) and copper-zinc with complex ores (c) (Ural type); 10 - gold-complex ore (a), gold-barite-complex ore (b) and 
gold (c) (Baymak type); 11 - cobalt-copper-zinc (Ivanovo type); 12 - boundaries of Magnitogorsk zone and first order zones (names in text); 13 - boundaries and numbers of VMS fields (names in text); 14 - transverse blocks; 15 - W-E faults.

Numerals on the map are names of deposits: 1 - Ivanovo, 2 - Dergamysh, 3 - Ishkinino, 4 - Tubinsk group, 5 - Kul-Yurt-Tau, 6 Uvaryazh, 7 - Bakr-Tau, 8 - Gornaya Baykara, 9 - Maysky, 10 - Tash-Tau, 11 - Tanalyk-Baymak, 12 - Semyonovka, 13 - Yulalinsky, 14 - Tuba-Kain, 15 - Balta-Tau, 16 - Yubileinoye, 17 - Buribay 18 - Makan group, 19 - Podolsk, 20 - Mambet, 21 - Gay, 22 - Bakr-Uzyak, 23 - Southern Bakr-Uzyak, 24 - Sibay, 25 - Uchaly, 26 - Ozerny, 27 - Uzelga, 28 - Molodyozhnoe, 29 - Tash Yar, 30 - Aleksandrinskiy, 31 - Issirguzhi, 32 - West Aschebutak, 33 - Dzhusa, 34 - Barsuchy Log, 35 - Letneye, 36 - Osenneye, 37 - Vesenneye, 38 - Amur, 39 Sabanov, 40 - Babarykin, 41 - East Podolsk.

Letters A-D in circles stand for names of transverse blocks $(a, b)$ : Uchaly (A), Magnitogorsk-Verkhneuralsk (B), Baymak-Katsbakh (C), Orsk-Dzhusa (D). Numerals 1-7 on the top map stand for names of W-E faults (b): Buyda (1), Beloretsk (2), Agapovka (3), Yulalinsky (4), Podolsk (5), Novocherkassk (6), and Orsk (7).

Рис. 2. Структурно-металлогеническая схема размещения колчеданных месторождений в вулканических комплексах Магнитогорской мегазоны [Seravkin, 2007] с добавлениями A.M. Косарева.

Формации: 1 - базальтовая $\left(\mathrm{O}-\mathrm{S}_{1}\right) ; 2$ - базальт-риолитовая $\left(\mathrm{D}_{1} \mathrm{e}_{2}\right)$ : контрастный (a) и непрерывный (b) комплексы; 3 - андезитобазальтовая $\left(\mathrm{D}_{2} \mathrm{ef}\right.$ ): базальт-андезибазальтовый (a) и гибридный базальт-андезит-риолитовый (b) комплексы; 4 базальтовая $\left(\mathrm{D}_{1} \mathrm{e}\right) ; 5$ - базальт-риолитовая $\left(\mathrm{D}_{2} \mathrm{ef}_{2}\right)$ : базальтовый $(\mathrm{a})$ и контрастный $(\mathrm{b})$, непрерывный (c) комплексы; 6 - андезитобазальтовая $\left(\mathrm{D}_{2}\right)(\mathrm{a})$, базальт-андезит-базальтовая $\mathrm{K}-\mathrm{Na}\left(\mathrm{D}_{3}\right)(\mathrm{b}) ; 7$ - базальт-андезит-риолитовая Юсинский (D $)(\mathrm{a})$, тоже Джусинский $\left(\mathrm{D}_{2} \mathrm{ef}_{1}\right)(\mathrm{b})$. Колчеданные месторождения: 8 - медноколчеданные (домбаровский тип) (a), цинковые (филизчайский тип) (b), 9 - цинково-медноколчеданные, $\mathrm{Cu}>\mathrm{Zn}(\mathrm{a})$, медно-цинковоколчеданные, Cu<Zn (b) и медно-цинковоколчеданные с полиметаллической минерализацией (c) (уральский тип); 10 - золото-колчеданно-полиметаллические (а), золото-барит-полиметаллические (b) и золото-колчеданные (c) (баймакский тип); 11 - кобальт-медно-цинково-колчеданные (ивановский тип); 12 - границы Магнитогорской зоны и структурно-формационных зон 1-го порядка (названия в тексте); 13 границы и номера колчеданоносных зон (названия в тексте); 14 - поперечные блоки; 15 - широтные дислокации.

Названия колчеданных месторождений: 1 - Ивановское, 2 - Дергамышское, 3 - Ишкининское, 4 - Тубинская группа, 5 - КульЮрт-тау, 6 - Уваряж, 7 - Бакр-тау, 8 - Горная Байкара, 9 - Майское, 10 - Таш-тау, 11 - Таналык-Баймакское, 12 - Семёновское, 13 - Юлалинское, 14 - Туба-Каин, 15 - Балта-тау, 16 - Юбилейное, 17 - Бурибайское, 18 - Маканская группа, 19 - Подольское, 20 - Мамбетовское, 21 - Гайское, 22 - Бакр- Узяк, 23 - Южный Бакр-Узяк, 24 - Сибайское, 25 - Учалинское, 26 - 0зерное, 27 Узельгинское, 28 - Молодежное, 29 - Таш-Яр, 30 - Александринское, 31 - Иссиргужинское, 32 - Западно-Ащебутакское, 33 Джусинское, 34 - Барсучий Лог, 35 - Летнее, 36 - Осеннее, 37 - Весеннее, 38 - Амурское, 39 - Сабановское, 40 - Бабарыкинское, 41 - Восточно-Подольское.

Буквы A-D в кружках обозначают названия поперечных блоков $(a, b)$ : A - Учалинский, В - Магнитогорско-Верхнеуральский, C - Баймакско-Кацбахский, D - Орско-Джусинский. Цифры 1-7 на верхней карте обозначают названия широтных дислокаций (b): 1 - Буйдинская, 2 - Белорецкая, 3 - Агаповская, 4 - Юлалинская, 5 - Подольская, 6 - Новочеркасская, 7 - Орская.

Middle Ordovician Tomino basalts of $\mathrm{Na}$, low-Ti, and lowCr tholeiite compositions [Kuzmin, 1985; Seravkin et al., 1992], associated with subalkaline basalts and with age constraints from conodonts in overlying limestones [Snachev, Mavrinskaya, 1995]. The Silurian Kosobrodsk and Katenin $\left(\mathrm{S}_{1-2}\right)$ complexes are composed of a continuous basalt-andesite-dacite-rhyolite calc-alkaline series [Seravkin et al., 1992]. Diorites with a U-Pb age of $429 \mathrm{Ma}$ in the southern flank of the Chelyabinsk granitic pluton (northern part of the paleovolcanic belt) host the North Tomino porphyry (Mo)-Au-Cu and Berezniki porphyry Au-Cu deposits (Fig. 3) [Grabezhev, 2009].

Early Devonian arc volcanism produced the Chanchar and Mostostroy volcanic complexes $\left(D_{1} e_{1}\right)$ found in the Sakmar zone at the junction of the Voznesenka-Sakmar serpentinite mélange and West Magnitogorsk zones near Orsk city, as well as the Ivanovo ( $\mathrm{D}_{1}$ ?), Buribay, and Upper Tanalyk $\left(\mathrm{D}_{1} \mathrm{e}_{2}\right)$ complexes with VMS mineralization (West Magnitogorsk zone) and the Kiembay complex (East Magnitogorsk zone). Early Devonian igneous rocks include peridotitic protrusions occurring as olistostrome layers or lenses of edaphogenic breccias. Such protrusions bear chromite mineralization [Pavlov et al., 1968; Perevozchikov, 2011] in the Main Ural Fault and in Mugodzhar Hills on its southern extension at the junction of the Bashkirian uplift with the Kraka-Sakmar and Uraltau zones, which makes up one of world largest chromite provinces [Pavlov et al., 1968;
Perevozchikov, 2011]. Judging by major-element, trace-element, and geodynamic signatures, chromites formed during selective melting of high-Ca boninites in a suprasubduction mantle wedge with participation of slab-derived aqueous fluids [Melcher et al., 1999; Perevozchikov, 2011].

The lower strata of the Voznesenka-Sakmar sections include sheets of serpentinite mélange with silicic-basaltic olistoliths, oceanic basalts $\left(\mathrm{O}_{2} ; \mathrm{S}_{1}\right)$, silicic rocks $\left(\mathrm{S}-\mathrm{D}_{1}\right)$, island arc gabbro, including hornblende gabbro and gabbrodiorites [Fershtater, 2013; Kosarev et al., 2014], shoshonites, and latites $\left(\mathrm{D}_{1}\right.$ ?). New to the zone Main Ural Fault is the allocation in its structure of the belt of volcanic rocks $\mathrm{D}_{1} \mathrm{e}_{2}$ analogues Baymak-Buribay suites and edaphogenic serpentinite-gabbro-silicic clastic complex is traced from Ishkinino-Repino to Voznesenska-Sharipovo.

The ages of peridotites can be extrapolated from available $\mathrm{Sm}-\mathrm{Nd}$ and $\mathrm{Rb}-\mathrm{Sr}$ ages of the Kempirsay gabbro, wehrlite, and clinopyroxenite [Edwards, Wasserburg, 1985; Melcher et al., 1999; Puchkov, 2010] which range from $427 \mathrm{Ma}$ to $379 \mathrm{Ma}$ (Late Silurian - Upper Devonian).

Magnitogorsk island arc system. Magmatic activity between the Lochkovian (Early Devonian) and Famennian (Late Devonian), from 418 to $359 \mathrm{Ma}$, produced several intrusive and volcanic complexes (see Fig. 1, 2; Fig. 3) with suprasubduction major- and trace-element signatures. The ages of volcanic complexes were constrained by conodonts (less often by other faunas) and by stratigraphic correlations 


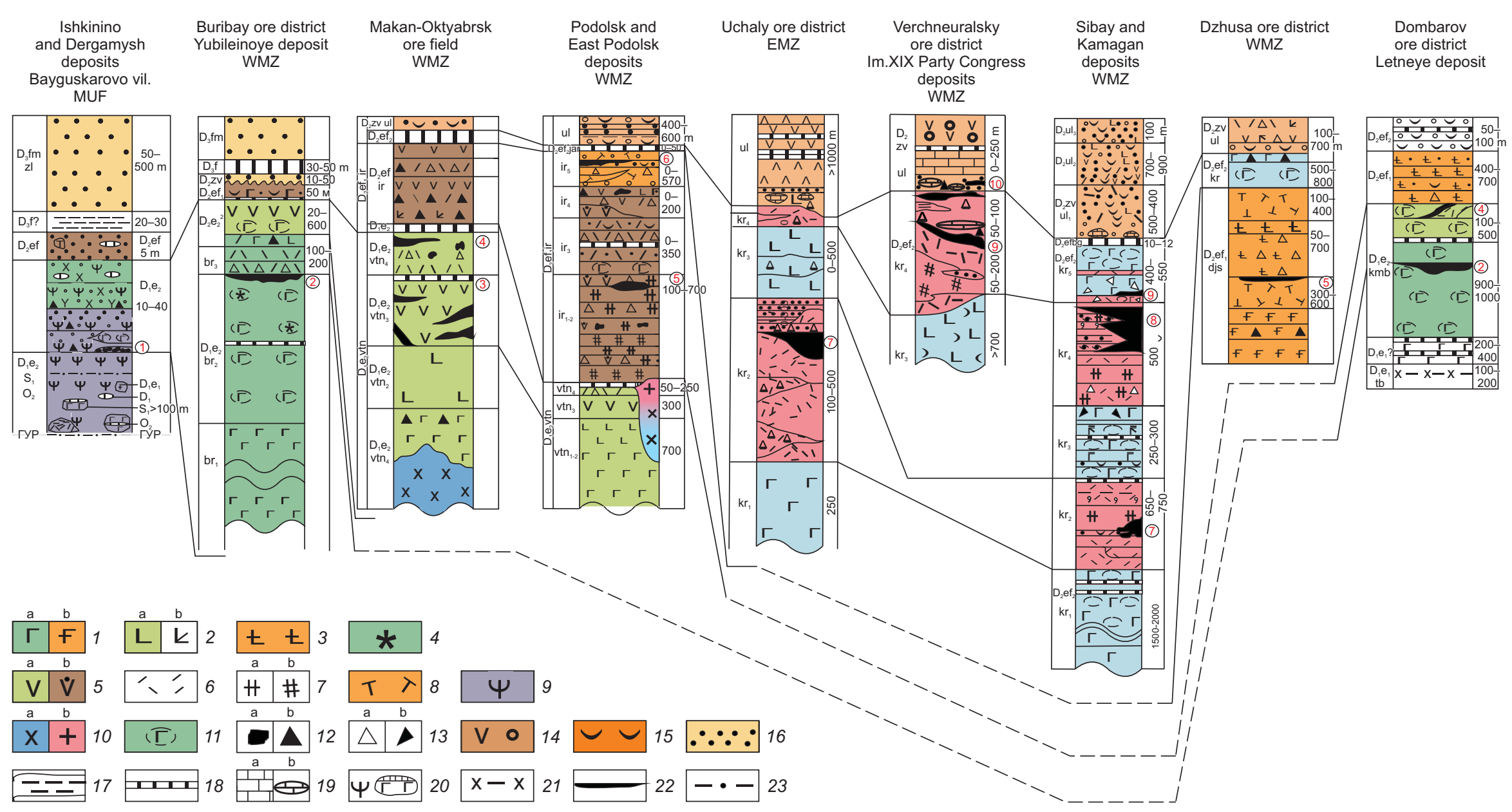

Fig. 3. Stratigraphic correlations of VMS complexes in the Magnitogorsk zone, South Urals. Compiled by A.M. Kosarev.

1-8 - volcanics: alkaline (a) and subalkaline (shoshonitic) (b) basalts (1), aphyric and plagiophyric (a) and pyroxene-porphyritic (b) basaltic andesites (2), shoshonites and latites (3), boninities and variolites (4), plagiophyric (a) and quartz-bearing (b) andesites (5), plagiophyric, quartz-plagioclase fine to medium porphyritic dacites and rhyodacites (6), magnophyric (a) and megaphyric (b) quartz-plagioclase rhyodacites (7), highly alkaline trachydacites and rhyodacites (8); 9 - serpentinized peridotites; 10 - intrusive rocks: gabbro-diorites and diorites (a), granites and granodiorites (b); 11 pillow lavas; 12 - blocks (a) and coarse clastic (b) agglomerate tuffs; 13 - fine clastic (a) and hyaloclastic (b) agglomerate tuffs; 14 - tuffs; 15 - tephroids; 16 - clastic sediments; 17 - siltstones; 18 - cherts and jaspers; 19 - massive (a) and detrital (b) limestones; 20 - serpentinite mélange with fragments of various compositions; 21 - Tulkubay Fm. green schists; 22 - VMS ore bodies; 23 - faults.

Рис. 3. Схема сопоставления и корреляции разрезов колчеданоносных вулканических комплексов Магнитогорской мегазоны на Южном Урале. Составлена А.М. Косаревым.

1-8 - эффузивные породы: 1 - базальты: (a) - нормальной щелочности, (b) - умеренно-щелочной (шошонитовой) серии, 2 - андезибазальты: (a) - афировые и плагиофировые, (b) пироксен-порфировые, 3 - шошониты-латиты, 4 - бониниты вариолитовые, 5 - андезиты: (а) плагиофировые, (b) - кварцсодержащие, 6 - дациты и риодациты плагиофировые, кварцплагиоклазовые мелкосреднепорфировые, 7- риодациты кварц-плагиоклазовые: (a) - крупнопорфировые, (b) - мегафировые, 8 - трахидациты, риодациты повышенной калиевости; 9 серпентинизированные ультрабазиты; 10 - интрузивные породы: (а) - габбро-диориты и диориты, (b) - граниты, гранодиориты; 11 - эффузивные породы с подушечной отдельностью; 12 - агломератовые туфы: (a) - глыбовые, (b) - крупнообломочные; 13 - (a) - агломератовые туфы мелкообломочные, (b) - гиалокластиты; 14 - туфы; 15 - тефроиды; 16 - терригенные породы; 17 - кремнистые алевролиты; 18 - кремни, яшмоиды; 19 - известняки: (а) - массивные, (b) - обломочные; 20 - серпентинитовый меланж с фрагментами различного состава; 21 - сланцы зеленосланцевой фации метаморфизма тюлькубайской толщи; 22 - рудные тела колчеданных месторождений; 23 - разрывные нарушения. 
[Seravkin etal., 1992; Stratigraphic Schemes..., 1993; Maslov et al., 1993; Puchkov, 2000, 2010; Kosarev et al., 2005; Maslov, Artyushkova, 2010].

The major event of Devonian volcanism consisted of four cycles: Early Devonian $\left(\mathrm{D}_{1} \mathrm{lh}-\mathrm{D}_{1} \mathrm{e}_{1}\right)$; Late Emsian - Early Eifelian $\left(\mathrm{D}_{1} \mathrm{e}_{2}-\mathrm{D}_{2} \mathrm{ef}\right)$; Late Eifelian - Early Frasnian $\left(\mathrm{D}_{2} \mathrm{ef}_{2}-\right.$ $\mathrm{D}_{3} \mathrm{f}_{1}$ ); and Late Devonian $\left(\mathrm{D}_{3} \mathrm{f}-\mathrm{D}_{3} \mathrm{fm}\right)$. The volcanics of the second $\left(D_{1} e_{2}-D_{2} e f{ }_{1}\right)$ and third $\left(D_{2} e_{2}-D_{3} f_{1}\right)$ cycles bear VMS ores. The first, second, and fourth cycles ended by eruptions of alkali shoshonites. Total alkalis and K contents show an increasing trend up the section in each cycle and throughout the major cycle from the Early to Late Devonian and from the frontal magmatic arc in the west to the back-arc region in the east (in present coordinates).

The Early Devonian arc $\left(\mathrm{D}_{1} \mathrm{lh}-\mathrm{D}_{1} \mathrm{e}_{1}\right)$ joins an Early Devonian intrusive complex [Fershtater, Krasnobaev, 2007; Fershtater, 2013, 2015] and includes the Mostostroi volcanic complex of subalkaline shoshonites, latites, and trachytes with a minor amount of picritic and alkali basalts [Tishchenko, 1971]. The $\mathrm{D}_{1} \mathrm{e}_{1}$ age of the complex was constrained by conodonts of the excavatus zone [Maslov, Artyushkova, 2010]. In addition to subalkaline volcanics, the Main Ural Fault zone accommodates numerous hornblende gabbro-diorite-plagiogranite and diorite-granodiorite intrusions with porphyry $\mathrm{Au}-\mathrm{Cu}$ mineralization (Voznesenka and Salavat deposits). The rocks have U-Pb [Grabezhev, Ronkin, 2011; Fershtater, 2013, 2015; Grabezhev, 2014] and Sm-Nd [Kosarev et al., 2014] ages from 418 to $399 \mathrm{Ma}$ (Lochkovian - Emsian). Similar ages were obtained for many intrusions with island arc trace-element signatures [Fershtater et al., 2010; Fershtater, 2013, 2015] and the author's data on Voznesenka and Karagaykul [Kosarev et al., 2014] which represent Early Devonian $\left(\mathrm{D}_{1} \mathrm{lh}-\mathrm{e}_{1}\right)$ magmatism.

The East Magnitogorsk zone includes the Early Devonian Dzhailgan back-arc complex of high-Ti subalkaline tephrite-trachybasalt rocks [Seravkin et al., 1992]. Dzhailgan complex arose in the rift, which lay on the edge of the EastUral zone (microcontinent?).

The Ivanovo, Buribay, and Upper Tanalyk complexes in the West Magnitogorsk zone represent an fore-arc.

The Early Devonian (?) Ivanovo volcanoplutonic complex is located in the Voznesenka-Sakmar zone and is composed of subalkaline tholeiite-boninite and arc tholeiite rock. Most of the Ivanovo basalts have high contents of $\mathrm{Mg}$ and $\mathrm{Na}$ but are low in Ti and K [Zaykov et al., 2001, 2009; Kosarev et al., 2005; Jonas, 2004; Nimis et al., 2010]. The arc tholeiites have low Mg contents [Zaykov et al., 2009] and host VMS or detrital pyrite mineralization: abundant pyrite, pyrrhotite, and chalcopyrite, as well as smaller amounts of cobaltite, arsenopyrite, or less often magnetite and chromite [Melekestseva, 2007]. VMS-Co-Cu deposits occur in serpentinite mélange (Ivanovo, Dergamysh, and Ishkinino deposits) and on the arc side of the trench (serpentinite-sedimentary breccias at the base of the complex, $\mathrm{D}_{1}$ ?).

The Late Emsian ( $D_{1} e_{2}$ br) Buribay volcanic complex belongs to the Tubinsk-Gay volcanic belt dated from conodonts of the serotinus-patulus zone [Maslov, Artyushkova, 2010]. The $>1000 \mathrm{~m}$ thick complex comprises tholeiite-boninite and calc-alkaline rocks (Fig. 4) [Spadea et al., 2002; Kosarev et al., 2005] and high-Ca boninites [Crawford et al., 1989]. The Buribay Ural-type VMS-Cu-Zn deposits $(\mathrm{Cu}>\mathrm{Zn})$ are of medium (Buribay) or large (Yubileinoye) sizes. The complex evolved from mafic to felsic compositions. Eruptions of subalkaline $\mathrm{Na}$ basalts with island arc signatures (lower dolerite-basalt unit) [Kosarev et al., 2005] were followed by pillow lavas proximal to oceanic flood basalts in $\mathrm{Ti}$ and $\mathrm{Zr}$ contents and in the $\mathrm{Th} / \mathrm{Yb}$ and $\mathrm{Nb} / \mathrm{Yb}$ ratios [Kosarev et al., 2005, 2015]. These features may represent a slab break off and slab-tear setting early during the complex history. It is also important that the plateau-basalts precede the formation of the VMS-bearing column of pillow-basaltsboninites. The question is whether plateau-basalts are involved in the petrogenesis of the basalt-boninite strata and in the formation of massive sulfide mineralization.

The Upper Tanalyk volcanic complex $\left(\mathrm{D}_{1} \mathrm{e}_{2}\right)$ of calc-alkaline high-Mg basalts, andesites, dacites, and rhyolites [Kosarev et al., 2005] lies over the Buribay complex and corresponds to the second cycle volcanism at the final stage of the Late Emsian arc in the West Magnitogorsk zone. The volcanics host Kuroko-type VMS-Au-complex ore deposits in the Baymak ore district, as well as Makan-Oktyabr'skoe and Gay ore fields [Prokin et al., 1988; Seravkin, 2010] (see Fig. 2, 3).

At the Late Emsian stage, large-scale eruptions of oceanic tholeiites with moderate Ti contents (Kiembay complex, $\mathrm{D}_{1} \mathrm{e}_{2}$ ) occurred in the Dombarovsky back-arc basin in the East Magnitogorsk zone, which inherited the Early Emsian back-arc basin [Seravkin et al., 1992]. The tholeiites combine mid-ocean ridge [Seravkin et al., 1992] and island arc trace-element signatures. The Kiembay basalts host Dombarovsky-type VMS-Cu deposits of medium sizes [Prokin et al., 1988].

Middle Devonian arc volcanism (mature arc). The Middle Devonian volcanism produced the Irendyk volcanic belt which is traceable in the $\mathrm{N}-\mathrm{S}$ direction from Karabash town to the Gay ore field (more than $400 \mathrm{~km}$ length, with 7-20 km wide outcrops) and includes the North Irendyk and South Irendyk complexes $\left(\mathrm{D}_{2} \mathrm{ef}_{1}\right)$.

The North Irendyk volcanic complex ( $\left.\mathrm{D}_{2} \mathrm{ef}\right)$ of tholeiitic island arc and calc-alkaline rocks builds large stratified cones with thephroids (see Fig. 2, 3). The volcanics bear geochemical signatures of a suprasubduction setting and fractional crystallization [Kosarev et al., 2014]. Ankaramite, trachybasalt, and trachyandesite rocks in the upper strata are transitional to subalkaline compositions [Kosarev et al., 2005; Pushkarev et al., 2013]. The complex lacks VMS mineralization.

The South Irendyk complex of $\mathrm{D}_{2}$ ef ${ }_{1}$ basalts, basaltic andesites, andesites, dacites, and rhyolites occupies the southern Irendyk zone (Buribay and Baymak ore districts). It is sandwiched between the Upper Tanalyk complex below and the Yarlykap jasper bed $\left(\mathrm{D}_{2} \mathrm{ef}_{2}\right)$ and the Ulutau Fm. above (see Fig. 2, 3). The lavas in the lower four units have a composition intermediate between island arc tholeiite and calcalkaline series (Fig. 4). The mineralogy of the Podolsk $\mathrm{Cu}>\mathrm{Zn}$ VMS field consists of pyrite, melnikovite, chalcopyrite, and 
sphalerite, with lesser amounts of bornite, tennantite, and galena [Sopko et al., 1983; Prokin et al., 1988].

Middle Devonian arc volcanism (back-arc) produced the Sukrak (West Magnitogorsk zone) and Dzhusa volcanic complexes.
Sukrak trachydacite complex $\left(\mathrm{D}_{2} \mathrm{e}_{1}\right)$ makes up the upper strata of Podolsk caldera volcano and is composed of pyroclastic, effusive, subvolcanic, and tephroid dacites and rhyodacites, often altered to redstone facies, with high $\mathrm{K}-\mathrm{Na}$ or Na contents. The Sukrak complex is transitional from (a)

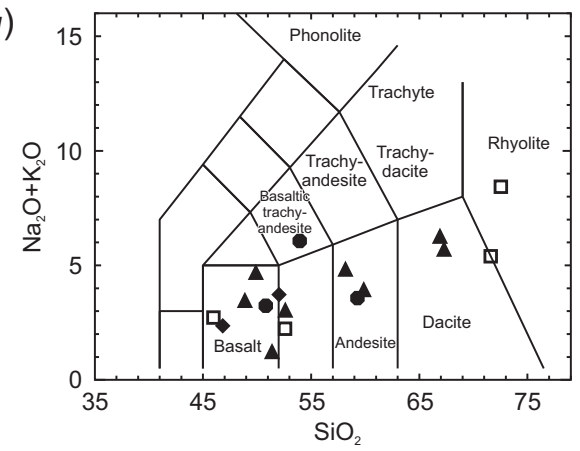

(c)

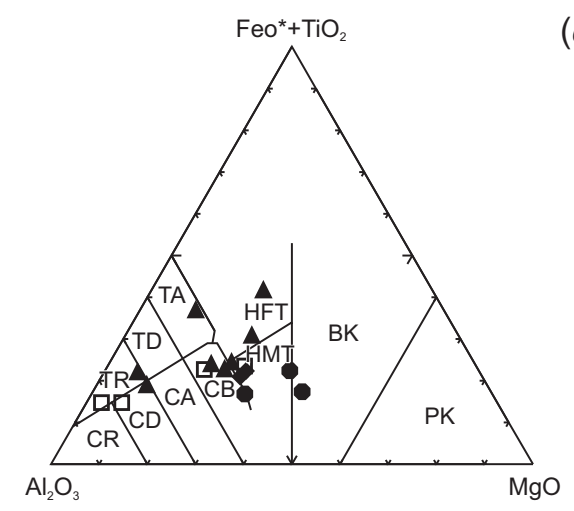

(b)

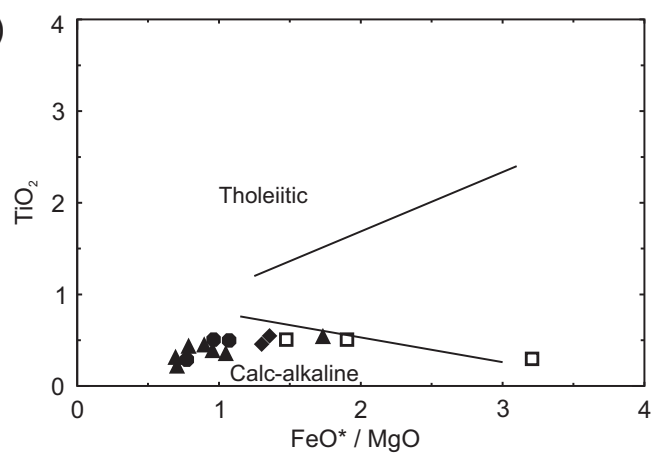

(d)

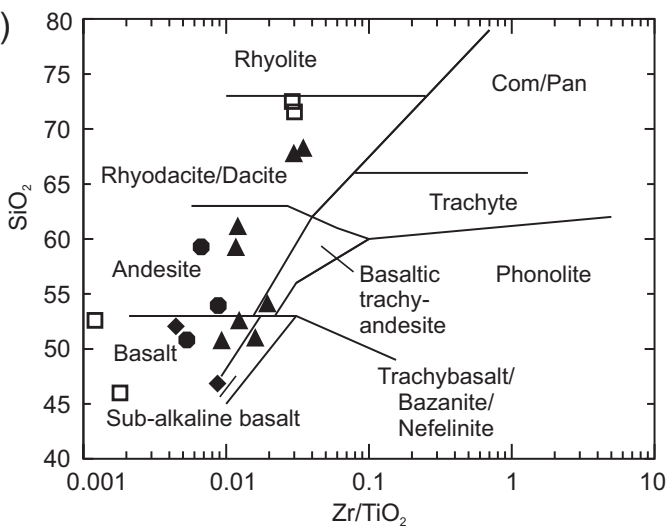

(e)

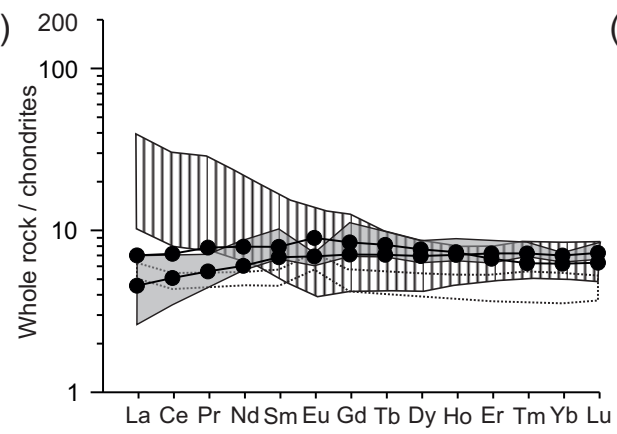

(f)

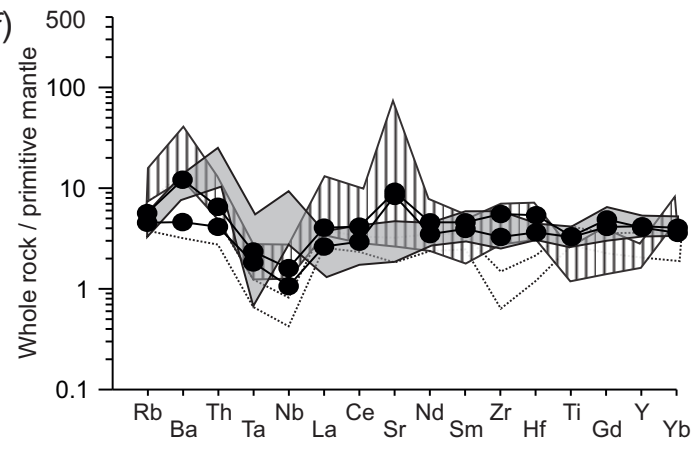

$\bullet-1 \quad \Delta$ 四 2

$2 \bullet \square 3 \quad \square \quad \square \quad 4$

Fig. 4. Major and trace element signatures of Early-Middle Devonian volcanics of the Magnitogorsk island-arc system.

1 - fore-arc and mature arc, including Buribay, $\mathrm{D}_{1}$ br; 2 - Upper Tanalyk, $\mathrm{D}_{1}$ vtn; 3 - North Irendyk; 4 - South Irendyk, $\mathrm{D}_{2}$ ef ${ }_{1}$ volcanic complexes, West Magnitogorsk zone. Rock compositions are after [Kosarev et al., 2005 and new materials of the author to the Baymak ore district]. (a-f) - discrimination diagrams: $(a)-\mathrm{TAS}$ [Le Maitre, 1989], (b) - $\mathrm{FeO}^{*} / \mathrm{MgO}^{-\mathrm{TiO}_{2}}$ [Miyashiro, 1974], $(c)-\mathrm{Al}_{2} \mathrm{O}_{3}-\mathrm{FeO}^{*}+\mathrm{TiO}_{2}-$ $\mathrm{MgO}$ [Jensen, 1976], $(d)-\mathrm{Zr} / \mathrm{TiO}_{2}-\mathrm{SiO}_{2}$ [Winchester, Floyd, 1977], (e) - chondrite-normalized REE spectra of basalts (normalized by the composition of chondrite [Boynton, 1984]), (f) - PM-normalized multi-element patterns of basalts (PM - Primitive Mantle) [Taylor, McLennan, 1985].

Рис. 4. Геохимические характеристики ранне- и среднедевонских вулканитов Магнитогорской островодужной системы. 1 - фронтальная и развитая островные дуги, в том числе вулканические комплексы включая бурибайский, $\mathrm{D}_{1} \mathrm{br} ; 2$ - Верхний Таналык, $\mathrm{D}_{1} \mathrm{vtn} ; 3$ - Северный Ирендык; 4 - Южный Ирендык, $\mathrm{D}_{2} \mathrm{ef}_{1}$ (3М3). При построении графиков использованы данные [Kosarev et al., 2005, и новые материалы автора по Баймакскому рудному району]. Дискриминационные диаграммы: (a) - TASдиаграмма, поля по [Le Maitre, 1989], (b) - диаграмма FeO*/MgO-TiO 2 Miyashiro, 1974], (c) - диаграмма $\mathrm{Al}_{2} \mathrm{O}_{3}-\mathrm{FeO}^{*}+\mathrm{TiO} \mathrm{O}_{2}-\mathrm{MgO}$ [Jensen, 1976], (d) - диаграмма $\mathrm{Zr} / \mathrm{TiO}_{2}-\mathrm{SiO}_{2}$ [Winchester, Floyd, 1974], (e) - спектры распределения РЗЭ в базальтах (нормировано по составу хондрита [Boynton, 1984]), (f) - мультиэлементные диаграммы для базальтов (нормировано по составу примитивной мантии [Taylor, McLennan, 1985]). 
calc-alkaline to shoshonite series that formed at the final stage of the Early Eifelian arc volcanism [Kosarev et al., 2005]. The complex hosts the East Podolsk deposit with high concentrations of $\mathrm{Ba}, \mathrm{Zn}$ and $\mathrm{Pb}$ which makes it similar to baritecomplex ore deposits of Rudny Altai.

The Dzhusa complex in the western flank of the Karabutak uplift in the East Magnitogorsk zone formed in the Early Eifelian, judging by constraints from conodonts, synchronously with the Irendyk Fm. of the West Magnitogorsk zone [Maslov, Artyushkova, 2010]. The complex is composed of alkaline and subalkaline [Tal'nov, 2003] basalts, andesites, dacites, and rhyolites; the rock compositions are generally of low-Ti island arc type which evolved from more mafic to more felsic types. Alkaline rocks are either sodic (4-7 \% $\mathrm{Na}_{2} \mathrm{O}$ and $0.3-2.5 \% \mathrm{~K}_{2} \mathrm{O}$ ) or potassium-sodic (3$7.7 \% \mathrm{Na}_{2} \mathrm{O}$ and $2.6-6.0 \% \mathrm{~K}_{2} \mathrm{O}$ ) varieties with shoshonitic major-element signatures typical of remnant arcs [Bogatikov, Tsvetkov, 1988]. The Early Eifelian volcanics of the complex host the Dzhusa, Barsuchy Log, and East Podolsk deposits of pyrite, chalcopyrite, sphalerite, galena, barite, and tennantite. The Dzhusa complex and its age equivalents in the East Magnitogorsk zone presumably build the detached remnant part at the back of the Early-Eifelian arc [Kosarev et al., 2014]. Later the spreading zone became occupied by the Late Eifelian Karamalytash basalt-rhyodacite complex and its age equivalents.

Late Eifelian volcanism produced the Karamalytash complex $\left(\mathrm{D}_{2} \mathrm{ef}_{2} \mathrm{~km}\right)$ and its age equivalents in the Karamalytash spreading zone extending for more than $700 \mathrm{~km}$ from the northern limits of the Magnitogorsk zone (Karabash town) as far as Orsk city and on into the Mugodzhar Hills, with up to 50-70 km wide outcrops. The spreading zone accommodates basalt-rhyolite and basalt volcanic complexes (see Fig. 2, 3). The basalt-rhyolite complex with VMS ( $\mathrm{Zn}>\mathrm{Cu}$ ) mineralization is composed of low-Ti alkaline basalts and dacite-rhyolite volcanics. The basaltic complex (Yuldashevo and Savelievo-Kalinovo) consists of subalkaline basalts and tholeiites with moderate or high Ti contents of within-plate type derived from asthenospheric diapirs (Fig. 5). The rocks of the Bolshoy Kumak complex vary in $\mathrm{SiO}_{2}$ from 44 wt. \% to 57 wt. \% and form a series from tephrites to benmoreites. Dacites and rhyodacites (Fig. 5) are alkaline or subalkaline varieties [Tal'nov, 2003]. The Karamalytash Fm. hosts the Uchaly deposit in the second $\left(\mathrm{km}_{2}\right)$ member of basoquartz rhyolite-dacite and the Sibay deposit in felsic rocks of the fourth $\left(\mathrm{km}_{4}\right)$ member (Uchaly and Sibay ore districts, respectively). The ore mineralogy of the Sibay field consists mainly of pyrite, chalcopyrite, and sphalerite, with lesser amounts of pyrrhotite, melnikovite, and magnetite, and rare galena, arsenopyrite, tennantite, bornite, and hematite [Prokin et al., 1988]. The fourth member of the Karamalytash Fm. $\left(\mathrm{km}_{4}\right)$ and the lower Ulutau Fm. ( $D_{2}$ zvul) bear ore bodies of the Upper Ural ore district (see Fig. 2), which thus lie stratigraphically higher than the Uchaly ores. The Uzelga ores comprise pyrite, chalcopyrite, sphalerite, tennantite, pyrrhotite, melnikovite, and markasite as main phases, with lesser amounts of arsenopyrite, magnetite, and galena [Prokin et al., 1988]. The Aleksandrinskiy VMS deposit occurs in the complex of the same name, which is an age equivalent of the Karamalytash Fm. $\left(\mathrm{D}_{2} \mathrm{ef}_{2}\right)$. The $\mathrm{Zn}$-Cu ore bodies have high $\mathrm{Pb}$ contents as in the Baymak-type deposits. The Aleksandrinskiy basalts have island arc tholeiite, calc-alkaline, or subalkaline compositions (Fig. 5).

The presence of voluminous oceanic basalts in the Karamalytash complex and its age equivalents provides evidence for oceanic crust production at the Karamalytash spreading axis. This interpretation is consistent with the predominant $\mathrm{Zn}-\mathrm{Cu}(\mathrm{Zn}>\mathrm{Cu}) \mathrm{VMS}$ mineralization with low concentrations of $\mathrm{Pb}$. The geochemical signatures of Early-Middle Devonian basalts make basis for the geodynamic and metallogenic division of the Magnitogorsk zone (Fig. 6).

Givetian arc volcanism produced the Givetian - Early Frasnian $\left(\mathrm{D}_{2} \mathrm{zv}-\mathrm{D}_{3} \mathrm{f}_{1}\right)$ Ulutau complex of calc-alkaline porphyritic basalts, andesites, and rhyolites with supra-subduction geochemical signatures, which are genetically related to the Karamalytash complex of a previous magmatic event. According to [Yazeva, Bochkarev, 1998; Surin, 1997] and the authors' data, most of the volcanics of the Ulutau complex belong to the porphyritic type (calcareous-alkaline series).

Late Devonian - Early Carboniferous magmatism. Frasnian-Famennian volcanism records the final phase of the Magnitogorsk island arc system $\left(D_{1-2}\right)$ when subduction gave way to a transform margin setting in the Late Devonian. The volcanics of that phase have mosaic distribution patterns and occur mainly in the western flank of the Magnitogorsk zone (Bogodak complex) [Maslov, Artyushkova, 2010].

The Frasnian event produced the Novo-Voronino complex $\left(D_{3} f\right)$ in the eastern flank of the Magnitogorsk zone, with alkali contents higher than in the underlying Ulutau complex [Kosarev et al., 2006]. The alkalinity increase appears in the Sheludivogorsk, Zingeyka, and Novoivanovo absarokite-shoshonite-latite complexes $\left(\mathrm{D}_{3} \mathrm{f}-\mathrm{fm}\right)$. The Sheludivogorsk and Novoivanovo shoshonite complexes in the East Magnitogorsk zone (see Fig. 2, 5), as well as the Berezniki complex $\left(\mathrm{D}_{3}-\mathrm{C}_{1}\right)$ of the Kachkar-Adamovka zone in the East Ural uplift, belong to a province of subalkaline volcanism that formed at the final phase of a mature island arc [Seravkin et al., 1992; Salikhov, Mitrofanov, 1994; Yazeva, Bochkarev, 1998; Tevelev, Kosheleva, 2002; Kosarev et al., 2006]. Famennian subalkaline basalts of the Ashchisuy Fm. $\left(D_{3}-C_{1}\right)$ are exposed on the northern side of the Middle Toguzak River in the eastern part of the East Ural paleovolcanic belt [Tevelev, Kosheleva, 2002]. They contain moderate amounts of $\mathrm{TiO}_{2}(0.69-1.44$ wt. \%) and high concentrations of MgO (10.1-12.02 wt. \%) and $\mathrm{K}_{2} \mathrm{O}$ (1.34-2.2 wt. \%), as well as $\mathrm{Rb}$ (21-32 ppm), Ba (1158-1400 ppm), Sr (350-394 ppm), Th (4.0-4.6 ppm), Nb (25-31 ppm), Zr (150-154 ppm), $\mathrm{La}(40 \mathrm{ppm})$, and $\mathrm{Yb}(2.0-2.2 \mathrm{ppm})$, with a $\mathrm{La} / \mathrm{Yb}$ ratio of 18.8-20. Their compositions are close to the within-plate type in $\mathrm{Nb}, \mathrm{Zr}$, and $\mathrm{Y}$ enrichment greater than the shoshonitic basalts from the South Urals $\left(D_{3}\right)$ and show neither $\mathrm{Nb}$ and $\mathrm{Zr}$ minimums nor a Sr maximum in the rock/N-MORB spider diagram. Later studies of this complex [Tevelev et al., 2006] revealed also basalts and trachybasalts with relatively low $\mathrm{Nb}$ contents (2.27-5.31 ppm) similar to the Berezniki rocks. Note that the $\mathrm{Nb}$ minimum is present in 
all Sheludivogorsk absarokites and shoshonites in the East Magnitogorsk zone (2-3 ppm Nb) [Kosarev et al., 2006; Tevelev, Kosheleva, 2002] but is absent or poorly pronounced in the Berezniki volcanics in the East Ural belt $\left(D_{3}-C_{1}\right)$ containing from 5.94 to 11 ppm Nb [Tevelev, Kosheleva, 2002; Tevelev et al., 2006].

(a)

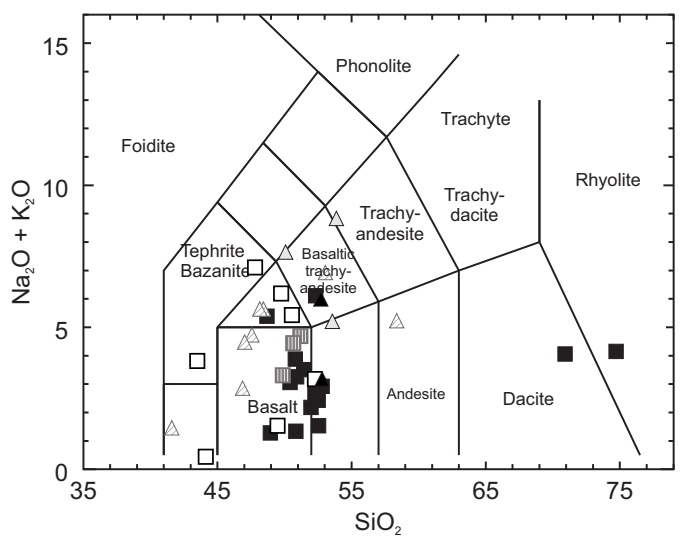

(c)

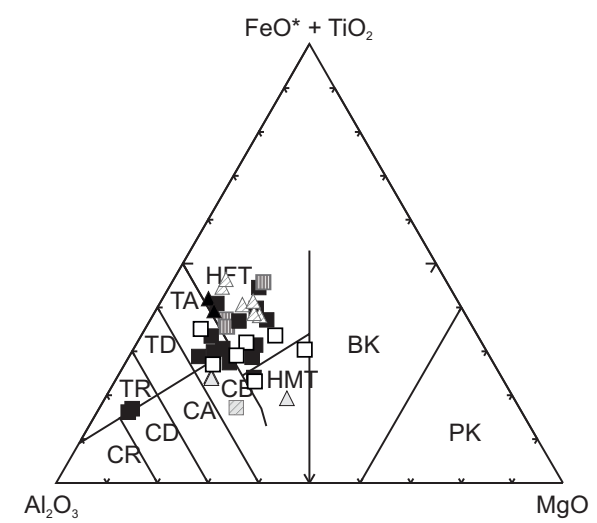

(e)

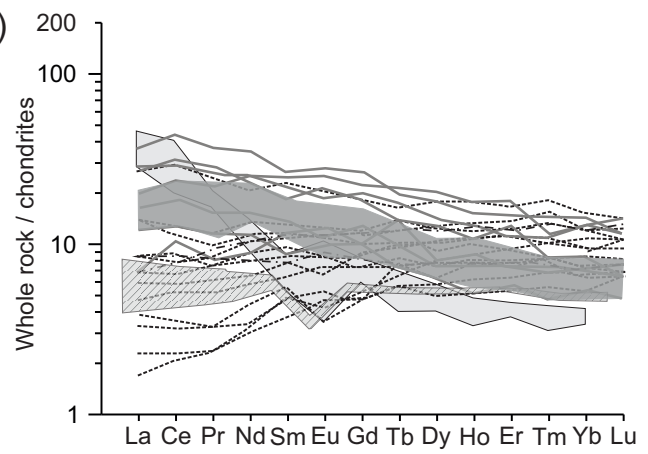

To sum up, the Devonian igneous rocks include shoshonite arc volcanics $\left(\mathrm{D}_{3} \mathrm{f}-\mathrm{fm}\right)$ in the East Magnitogorsk zone [Kosarev et al., 2006]; within-plate subalkaline basalts ( $D_{3} \mathrm{fm}$ ) of local occurrence in the East Ural uplift (Middle Toguzak River) [Tevelev, Kosheleva, 2002; Tevelev et al., 2006]; shoshonite basalts with relatively high $\mathrm{Nb}$ contents in the Berezniki

(b)

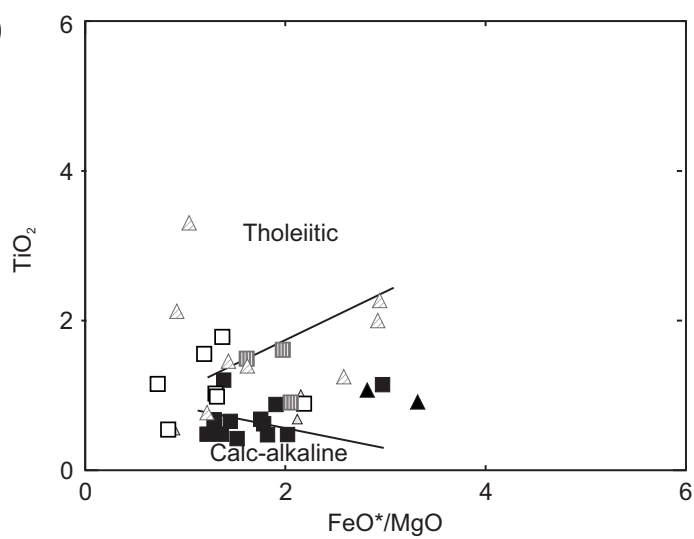

(d)
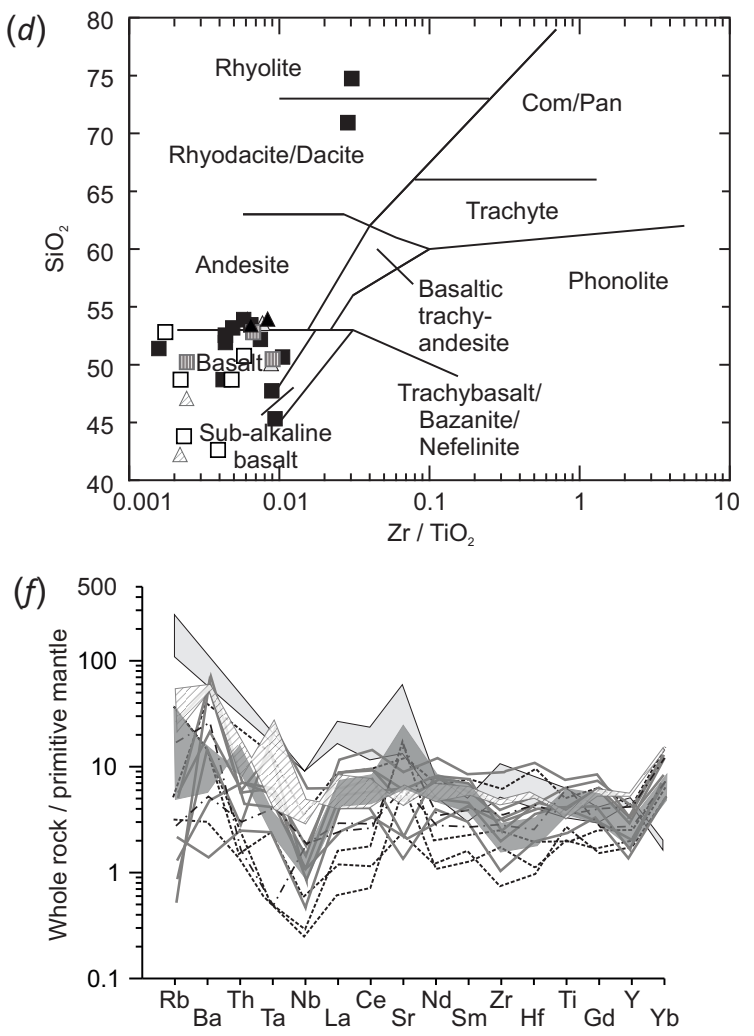

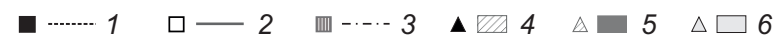

Fig. 5. Major and trace element signatures signatures of Middle-Late Devonian volcanics of the Magnitogorsk island-arc system. 1 - arc-spreading Karamyltash volcanic complex, Sibay and Uchaly ore districts, $\mathrm{D}_{2} \mathrm{ef}_{2}$ (West Magnitogorsk zone); 2 - same for Alexandrinskiy ore district, back-arc region; 3 - Yuldashevo barren zone; 4 - Savelievo-Kalinovo barren zone; 5 - Bolshoy Kumak barren complex, basal hawaiites in the $\mathrm{D}_{2}$ ef $\mathrm{f}_{2}$ section; 6 - Sheludivogorsk shoshonitic trachybasalts and trachyandesites, $\mathrm{D}_{3}$ fr-fm (East Magnitogorsk zone). Rock compositions are after [Tal'nov, 2003; Yazeva, Bochkarev, 1998; Kosarev et al., 2006]. Legend same as in Fig. 4.

Рис. 5. Геохимические характеристики средне-позднедевонских вулканитов Магнитогорской островодужной системы. 1 - внутридуговый спрединг, карамылташский вулканический комплекс Сибайского и Учалинского рудных районов, $\mathrm{D}_{2} \mathrm{ef}_{2}$ (3М3); 2 - то же Александринского рудного района тыловой зоны; 3 - безрудной Юлдашевской зоны; 4 - безрудной Савельевско-Калиновской зоны; 5 - безрудный большекумакский комплекс гавайитовой серии основания $\mathrm{D}_{2} \mathrm{ef}_{2}$ разреза; 6 - трахибазальты, трахиандезибазальты шошонитовой серии шелудивогорского комплекса ( $\mathrm{D}_{3} \mathrm{fr}-\mathrm{fm}$ ?) (BM3). При построении графиков использованы данные [Tal'nov, 2003; Yazeva, Bochkarev, 1998; Kosarev et al., 2006]. Условные обозначения см. рис. 4. 
complex (Kachkar-Adamovka zone of the East Ural uplift). The subalkaline volcanics make up a series changing in the $\mathrm{W}$-E direction from arc shoshonite-absarokite in the Sheludivogorsk complex $\left(\mathrm{D}_{3} \mathrm{f}\right)$, to the Berezniki Nb-enriched shoshonites $\left(D_{3}-C_{1}\right)$, and on to the Ashchisuy within-plate basalts $\left(D_{3} \mathrm{fm}\right)$ and varieties transitional to absarokites $\left(D_{3}-C_{1}\right)$ [Tevelev, Kosheleva, 2002]. The complexes of within-plate rift-related basalts and those transitional to the suprasubduction type apparently formed in a setting of a transform boundary and suprasubduction asthenospheric diapirism [Martynov, Khanchuk, 2013]. Both volcanic and intrusive rocks have relatively high enrichment in iron and alkalis (especially $\mathrm{K}_{2} \mathrm{O}$ ), LREE, $\mathrm{Rb}, \mathrm{Sr}, \mathrm{Hf}$, Th, and $\mathrm{Zr}$; the $\mathrm{La} / \mathrm{Yb}$ ratios vary from 7.7 to 11.3 in absarokites and shoshonites and reach 20.5 in banakites. The geochemical signatures suggest increasing metasomatic LILE enrichment of the depleted mantle wedge [Tatsumi et al., 1986; Pearce et al., 1984]. Most likely, slab break off and asthenospheric diapirism were responsible for mantle enrichment in LILE and $\mathrm{H}_{2} \mathrm{O}$ from slab-derived fluids [Martynov, Khanchuk, 2013; Chemenda et al., 1997; Puchkov, 2000; Kosarev et al., 2014].

The Ashchisui volcanic $\left(D_{3}-C_{1}\right)$ and Mikheevka intrusive (diorite-granodiorite-granite-porphyry) complexes host the Mikheevka porphyry (Mo)-Au-Cu deposit. The upper Ashchisui Fm. in the area is composed of silicites, arkose and quartz sandstones, siltstones, tuffaceous sandstones, xenoclastics, and tuff conglomerates [Tevelev et al., 2006], while the lower strata include andesites, basaltic andesites, and less often felsic volcanics. Mafic and intermediate rocks are mainly alkaline, while some intermediate varieties (latites

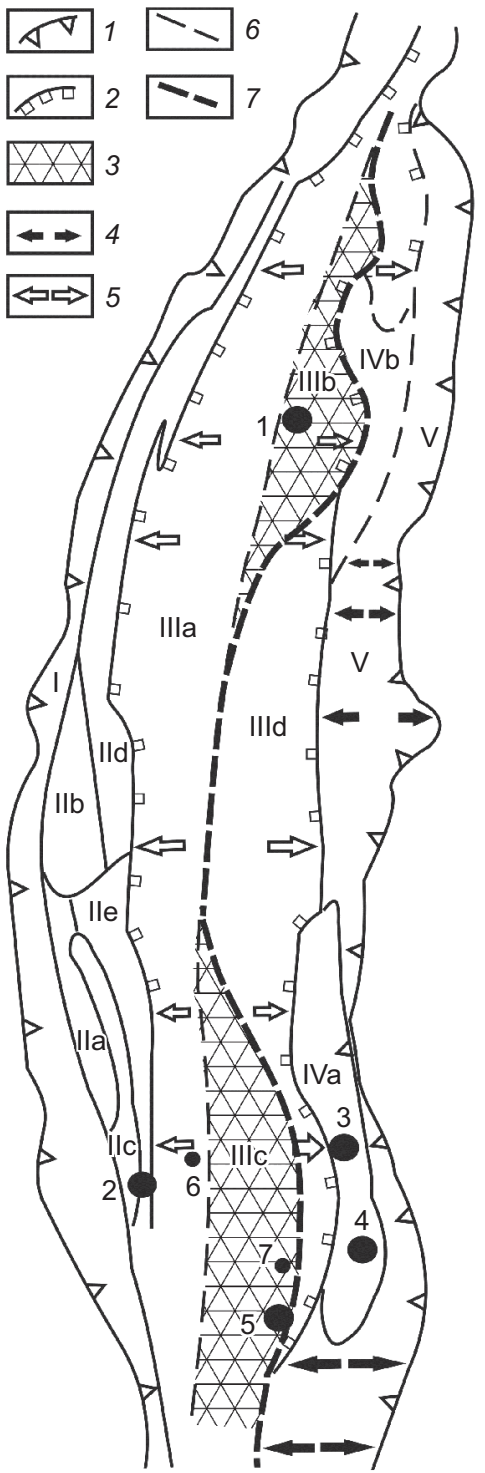

Fig. 6. Reconstructed Late Emsian - Eiffelian geodynamic settings of the Magnitogorsk zone.

1 - boundaries of Magnitogorsk zone; 2 - limits of arc spreading; 3 - suprasubduction back-arc fragments; 4 - back-arc and oceanic rifting $\left(\mathrm{D}_{1} \mathrm{e}_{1}-\mathrm{e}_{2}\right) ; 5$ - spreading basin $\left(\mathrm{D}_{2} \mathrm{ef}\right) ; 6$ - contours of thermal field minimum (a fragment); 7 - reconstructed Eifelian slab edge projection. Roman numerals stand for names of zones and complexes: I - Voznesenka-Sakmar zone (MUF); II - magmatic arc fragment in West Magnitogorsk zone: IIa - Buribay volcanic complex $\left(\mathrm{D}_{1} \mathrm{e}_{2}{ }^{\prime}\right)$, IIb - Upper Tanalyk complex $\left(\mathrm{D}_{1} \mathrm{e}_{2}{ }^{\prime \prime}\right)$, Baimak ore district, IIc - Upper Tanalyk complex ( $\mathrm{D}_{1} \mathrm{e}_{2}$ )', Makan-Gay subzone, Tubinskiy-Gay paleovolcanic belt, IId-e - North Irendyk and South Irendyk complexes $\left(\mathrm{D}_{2} \mathrm{ef}_{1}\right)$; III - Karamalytash arc complex and its age equivalents: IIIa - suprasubduction zone, IIIb-IIIc - suprasubduction back-arc basin, Aleksandrinskiy and Aschebutak-Central Orsk areas, IIId - Karamalytash arc complex outside subduction zone; IV - Dzhusa (IVa) and Lower Zingeyka (IVb) fragments of split (remnant) arc $\left(\mathrm{D}_{2} \mathrm{ef}_{1}\right)$ in East Magnitogorsk zone; $\mathrm{V}$ - backarc spreading zone $\left(\mathrm{D}_{1}\right.$ ?). Arabic numerals stand for names of VMS deposits: 1 - Aleksandrinskiy, 2 - Gay, 3 - Dzhusa, 4 - Barsuchiy Log, 5 - Aschebutak, 6 - Yusa, 7 - Issirguzhi.

Рис. 6. Реконструкция геодинамических обстановок Магнитогорской мегазоны, срез - поздний эмс-эйфель.

1 - границы Магнитогорской мегазоны; 2 - границы зоны внутридугового спрединга; 3 - фрагменты надсубдукционной зоны тыловодужной позиции; 4 - зона задугового субконтинентального и океанического рифтогенеза $\left(\mathrm{D}_{1} \mathrm{e}_{1}-\mathrm{e}_{2}\right)$; 5 - зона внутридугового спредингового бассейна ( $\left.\mathrm{D}_{2} \mathrm{ef}\right) ; 6$ фрагмент контура минимума теплового поля; 7 - проекция реконструированного края субдукционной плиты в эйфельское время. Цифровые обозначения: I - Вознесенско-Присакмарская зона (ГУР), II - фрагмент фронтальной и развитой островной дуги в Западно-Магнитогорской зоне: IIa - площадь распространения бурибайского вулканического комплекса $\left(\mathrm{D}_{1} \mathrm{e}_{2}{ }^{\prime}\right) ; \mathrm{IIb}$ - то же, верхнетаналыкского комплекса $\left(\mathrm{D}_{1} \mathrm{e}_{2}\right.$ ") Баймакского рудного района; IIc - то же верхнетаналыкского комплекса ( $\mathrm{D}_{1} \mathrm{e}_{2}$ ) Маканско-Гайской подзоны Тубинско-Гайского палеовулканического пояса; IId, IIe - северо-ирендыкского и южно-ирендыкского комплексов $\left(\mathrm{D}_{2} \mathrm{ef}_{1}\right)$; III - область распространения карамалыташского внутридугового комплекса и его возрастных аналогов: IIIa - над зоной субдукции, IIIb, IIIc - над зоной субдукции, тыловодужная обстановка, Александринская и Ащебутакско-Среднеорская площади, IIId - область распространения карамалыташского внутридугового комплекса вне влияния зоны субдукции (субокеаническая обстановка); IV - фрагменты отщепленной (остаточной) островной дуги ( $\mathrm{D}_{2} \mathrm{ef}_{1}$ ) в BM3: IVa - джусинский, IVb - нижнезингейский; $\mathrm{V}-$ зона задугового (D ?) спрединга. Колчеданные месторождения: 1 - Александринское, 2 - Гайское, 3 - Джусинское, 4 - Барсучий Лог, 5 - Ащебутакское, 6 Юсинское, 7 - Иссиргужинское. 
and trachyandesites) are subalkaline. The Mikheevka quarry exposes numerous NEN fault contacts between igneous and sedimentary rocks with low-angle to horizontal or less often high-angle striation on slickensides, which records oblique reverse slip motions in the ore-bearing rocks.

Deep boreholes stripped pillow basalts $\left(\mathrm{D}_{1}\right.$ ?) with layers of carbonaceous and siliceous rocks, clastic carbonaceous chert, and volcanic-sedimentary lithologies $\left(\mathrm{S}_{1-2}\right)$ below the Ashchisui Fm. in the sides of the Mikheevka basin. U-Pb zircon ages of $356 \mathrm{Ma}$ and $362 \mathrm{Ma}$ are available, respectively, for altered granitoids in the Mikheevka and Tarutino fields, which span the $\mathrm{D}_{3} \mathrm{fm}-\mathrm{C}_{1} \mathrm{t}_{1}$ interval from the Upper Famennian to the lower Tournaisian [Grabezhev, 2009]. Note that the 380-360 Ma interval corresponds to the time of the first large-scale pulse of granitic magmatism [Fershtater, 2013, 2015].

Thus, the East Magnitogorosk and East Ural zones underwent suprasubduction subalkaline magmatism of a declining island arc and transition to a within-plate setting in the Upper Devonian - Lower Carboniferous. Volcanic eruptions and intrusions record a combination of subduction and transform settings, similar to that in Cenozoic orogens of Pacific Asia.

Geodynamic factors and VMS mineral potential of Devonian complexes. The volcanics of two VMS-bearing cycles $\left(D_{1} e_{2}-D_{2}\right.$ ef $f_{1}$ and $D_{2}$ ef $\left.-D_{3} f_{1}\right)$ progressively decrease in volume of boninites and tholeiites at increasing calc-alkaline and shoshonite varieties. These trends may record slab sinking (see Fig. 4, 5), increasing magma generation depths, and decreasing amounts of slab-derived fluids from the front to the back of the arc system. The amount of slab-derived fluids controls the melting process and the melt fraction in the mantle wedge. Felsic volcanics that erupted at final evolution stages of VMS-bearing complexes were probably derived from lower basaltic crust molten upon interaction with the top of an asthenospheric diapir [Fershtater, 2013].

The volcanic complexes in the Magnitogorsk island arc system differ in their VMS potential (Fig. 6). The grades are the highest in (a) bimodal suprasubduction tholeiite-boninite-rhyodacite and transitional to calc-alkaline mature arc series, as well as in (b) bimodal tholeiite-rhyodacite suprasubduction arc series of the spreading basin occupied by the Karamalytash complex (see Fig. 5; Fig. 6). Small and medium VMS occurrences exist in suprasubduction complexes of calc-alkaline (Baymak), subalkaline (Dzhusa, Barsuchy Log), and transitional tholeiitic to calc-alkaline (Aleksandrinskiy) compositions, as well as in basaltic (Osenneye and Letneye deposits) and contrasting (Akzhar occurrence) complexes of the back-arc basin $\left(\mathrm{D}_{1} \mathrm{e}_{2}\right)$. Low grades are observed in transitional and oceanic subalkaline and tholeiite complexes. The systematic change of intrusive and volcanic belts which bear $\mathrm{Co}-\mathrm{Cu} \rightarrow \mathrm{Cu}-\mathrm{Zn} \rightarrow \mathrm{Zn}-\mathrm{Cu} \rightarrow \mathrm{Zn}-\mathrm{Cu}-\mathrm{Au}-\mathrm{Ba}-\mathrm{Pb}$ massive sulfide deposits within the Magnitogorsk island arc system is apparently related to Paleozoic subduction and rifting events in the region [Kosarev et al., 2010].

Aleksandrovka island arc system $\left(D_{3} ?-C_{1}\right)$. Volcanic complexes and tonalite-granodiorite intrusions (Fig. 7) identified reliably in the Trans-Ural and East Ural zones
(Chelyabinsk granitoid intrusive complex) fall within a time span of 360 to $345 \mathrm{Ma}$ [Seravkin et al., 1992; Fershtater, 2013]. The Early Carboniferous was the time of another key tectonic event in the history of the South Ural orogen, which ended with collisional volcanism in the Magnitogorsk-Bogdanovskiy graben $\left(\mathrm{C}_{1} \mathrm{t}_{2}-\mathrm{v}_{1}\right)$ followed by synorogenic collapse with the ensuing diverse mafic and granitic magmatism over the whole territory $\left(\mathrm{C}_{2-3}-\mathrm{P}\right)$ [Fershtater, 2013]. The sub-plate evolution stage was almost amagmatic, except for the Kisiney granite-porphyry complex [Tevelev et al., 2009]. Numerous dispersed fragments of ultramafic rocks and serpentinite mélange provide direct evidence of a tectonic event associated with the decline of the Magnitogorsk island arc system and the origin of another arc of Aleksandrovka over a slab dipping in the opposite direction. Note that this model is consistent with seismics images across the South Urals which confirm the existence of bi-vergent orogens [Puchkov, Svetlakova, 1993; Puchkov, 2000, 2010]. The possibility of a structural-geodynamic model of the Southern Urals with a subduction zone of eastern vergence in the Trans-Ural zone was previously suggested by K.S. Ivanov, V.N. Puchkov, A.M. Kosarev and G.A. Mizens. In this respect, it is reasonable to discuss the Early Carboniferous magmatism successively for the island arc and collisional stages that completed the regional volcanic activity.

The Trans-Ural zone includes several Early Carboniferous N-S arc belts (see Fig. 1), with volcanic and intrusive complexes of the Troitsk-Kengussay, Aleksandrovka, Oktyabr'skoe-Denisovka, Valerianovka, and Borovska zones. The Oktyabr'skoe-Denisovka zone is separated by the Livanov fault from the Valerianovka zone and by the Tobol strike-slip fault marked by numerous peridotitic and serpentinite bodies from the Aleksandrovka zone [Seravkin et al., 1992]. The Valerianovka zone is an area of especially intense Early Carboniferous andesitic volcanic-plutonic magmatism [Dymkin, 1966; Poltavets et al., 1988; Seravkin, 2010] which hosts the principal iron belt of Turgay traceable for over $800 \mathrm{~km}$ [Seravkin et al., 1992]. The metallogeny consists mainly of skarn Ti-magnetite deposits controlled by large circular volcanoplutonic structures: paleo-calderas and volcanic cones that are composed of calc-alkaline basaltic andesites and comagmatic gabbro-diorite-granodiorite intrusions $\left(\mathrm{C}_{1}\right.$ ) [Fershtater, 2013].

The Aleksandrovka zone encompasses abundant basaltic andesites and andesites $\left(\mathrm{C}_{1}\right)$ of the Aleksandrovka complex and coeval tonalite-granodiorite intrusions. A reference section of this type was sampled by one of us (A.M.K.) along the Kartaly-Ayat River. As shown by diagrams in Fig. 7, the basalts of the complex have high contents of $\mathrm{Al}$ (up to 19.6 wt. $\% \mathrm{Al}_{2} \mathrm{O}_{3}$ ), relatively high $\mathrm{K}_{2} \mathrm{O}$ (up to $1.7 \mathrm{wt} . \%$ ), and low or moderate concentrations of $\mathrm{Ti}, \mathrm{Cr}, \mathrm{Ni}, \mathrm{Co}, \mathrm{Zr}$, and LREE; all volcanics show high concentrations of Sr (2500$850 \mathrm{ppm}$ ). The Aleksandrovka volcanics plot within the calc-alkaline and subalkaline fields common to mature arc compositions (Fig. 7). The extremely large skarn magnetite deposits of the Valerianovka zone and the Aleksandrovka occurrences are typical of andesitic volcanoplutonic belts. Judging by the distribution of volcanics and comagmatic 
intrusives $\left(\mathrm{C}_{1}\right)$, the Aleksandrovka arc covers the Magnitogorsk zone in the west and the Trans-Ural zone in the east. The northern Tyumen-Kostanay basin accommodates the Tyumen and Kurgan Trans-Ural intrusive series comparable with Frasnian rocks from the Valerianovka zone $\left(\mathrm{D}_{3} \mathrm{f}\right)$ [Poltavets, 2009], which record the onset of magmatism in the island arc system in the Upper Devonian $\left(D_{3} f\right)$.

Thus, the Valerianovka, Aleksandrovka, and East Ural zones can be interpreted, respectively, as a frontal, transitional, and back-arc structures in terms of the Early Carboniferous suprasubduction magmatism. In this case, potassic subalkaline basalts of the post-island arc stage may represent the subsequent events of asthenospheric diapirism and rifting (Magnitogorsk zone, East Ural volcano-plutonic belt).

Transform-collisional volcanism in South Urals $\left(\mathrm{C}_{1}\right)$. The region underwent transform-collisional volcanism in the Early Carboniferous, during the decline of the Aleksandrovka island arc system and the change from subduction to a transform margin setting, with the ensuing break off of a fixed slab. Volcanism was associated with compression of island arc complexes that were involved in transform strike-slip motions at the continent-ocean transition. The earliest event of orogenic volcanism began in the Early (a)

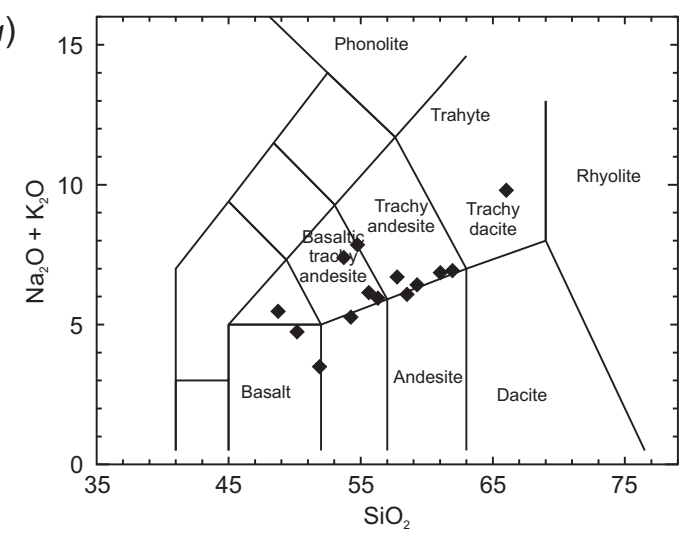

(c)

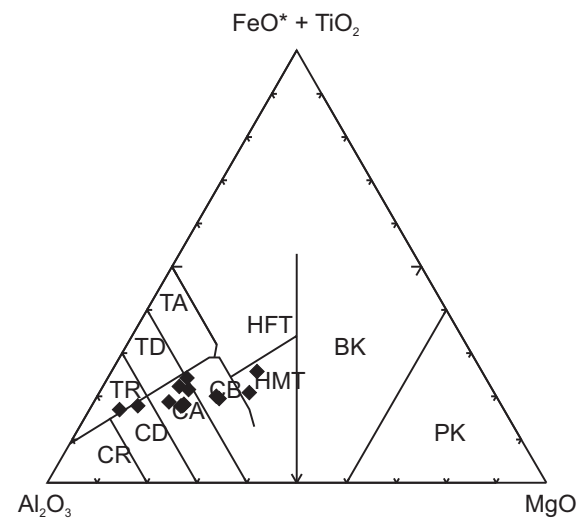

(e)

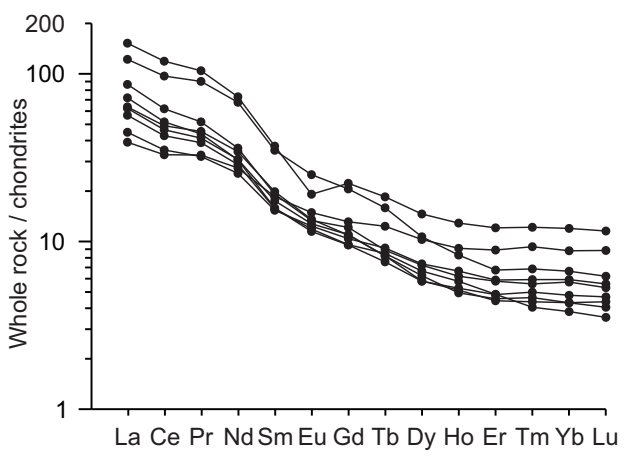

(b)

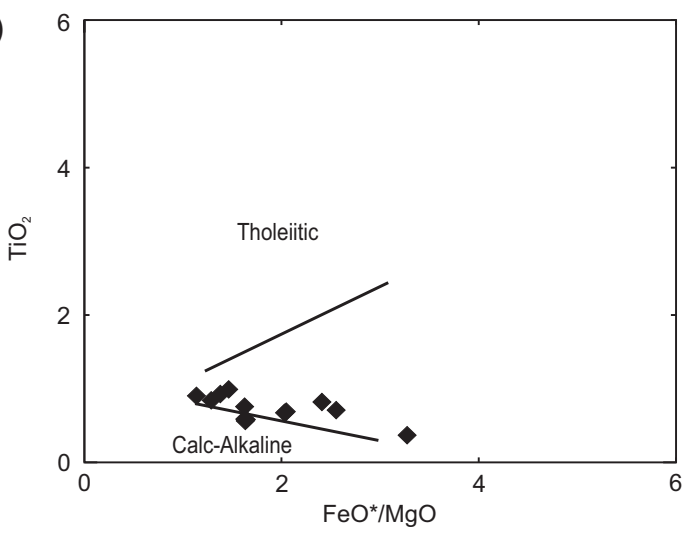

(d)

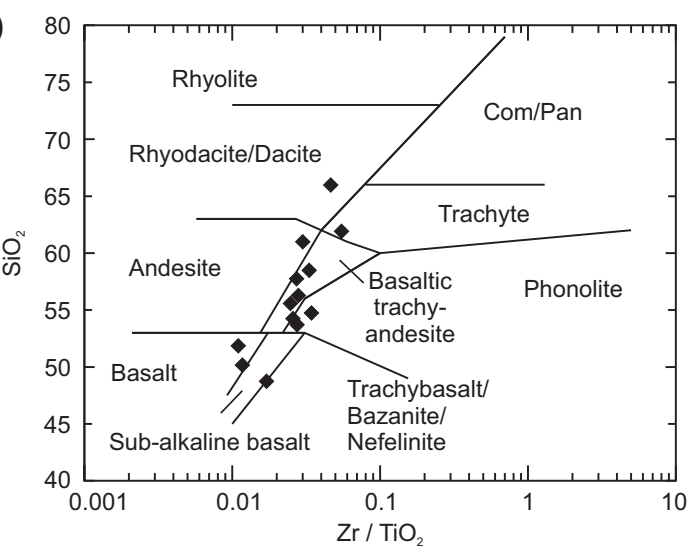

(f)

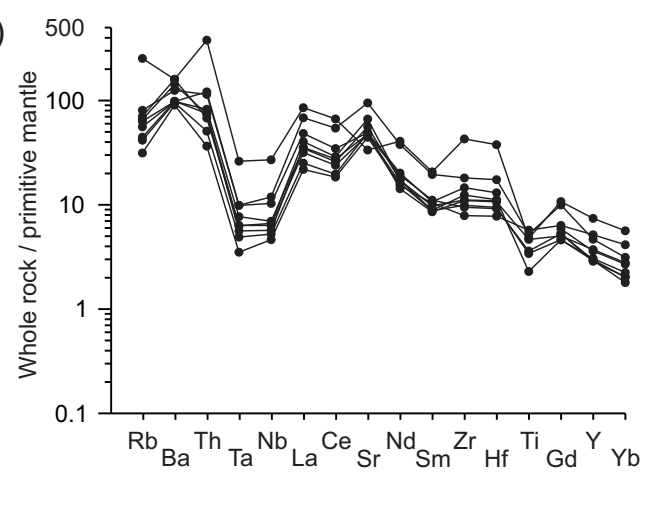

Fig. 7. Major and trace element signatures signatures of Early Carboniferous volcanics of the Aleksandrovka island-arc system (TransUral area). New data rock compositions of the Aleksandrovka volcanic complex $\left(\mathrm{C}_{1}\right)$ were used. Legend same as in Fig. 4.

Рис. 7. Геохимические характеристики раннекаменноугольных вулканитов Александровской островодужной системы (Зауралье). При построении графиков использованы новые данные по александровскому вулканическому комплексу, $\mathrm{C}_{1}$. Условные обозначения см. рис. 4. 
(a)

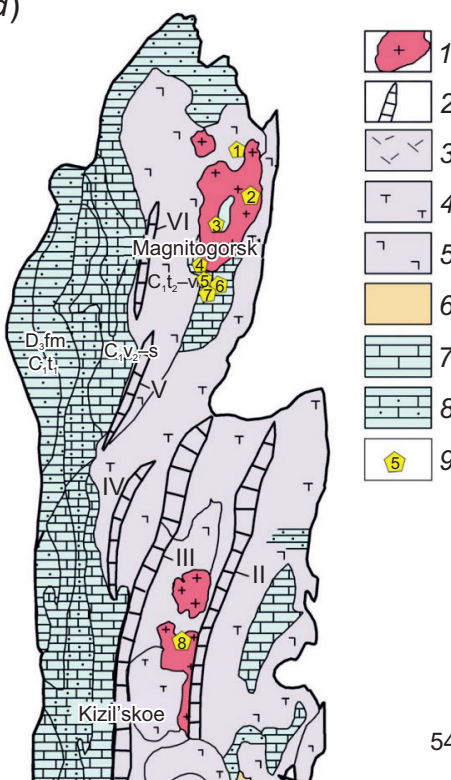

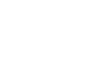

(b) 
27 - Neplyuevka, Tolstinskiy, 28 - Suunduk, 29 - Tolstinskiy. Roman numerals stand for names of major tectonic units: I - East European craton, II - Magnitogorsk zone, III - East Ural zone, IV - Trans-Ural zone.

Рис. 8. Схема распространения гранитоидных массивов Магнитогорской и Восточно-Уральской мегазон с палеовулканической врезкой Магнитогорско-Богдановского грабена, Южный Урал. Составлена Д.Н. Салиховым, И.Р. Рахимовым и Т.А.Осиповой на основе материалов [Sobolev, 1971].

$(a)$ - палеовулканическая карта Магнитогорско-Богдановского грабена. 1 - интрузивы гранитоидные; 2 - палеораздвиги; 3-5 - вулканиты: 3 - кислые, 4 - трахидацитовые, 5 - базальтоидные; 6 - островодужные комплексы девона; 7 - карбонатные отложения; 8 - вулканотерригенные отложения; 9 - железорудные месторождения проявления: 1 - Ивановское, 2 - Малый Куйбас, 3 - Башик, 4 - Димитровское, 5 - Берёзки, 6 - Подотвальное, 7 - Магнитогорское, 8 - Микубай-Мартыновское, 9 Грязнушинское, 10 - Полевое, 11 - Малокараганское, 12 - Богдановское. Римскими цифрами обозначены раздвиги: I - Гусихинский, II - Жарумбайский, III - Центральный, IV - Уральский, V - Западный, VI - Кирсинский.

(b) - схема распространения гранитоидных массивов Магнитогорской и Восточно-Уральской мегазон. 1-3 - вулканогенноосадочные комплексы: 1 - ранне- и среднепалеозойские нерасчлененные, 2 - девонские, 3 - каменноугольные; 4 - офиолитовые комплексы; 5 - границы Магнитогорско-Богдановского грабена; 6-12 - гранитоиды разных формационных типов: 6 - гранитный, 7 - гранит-лейкогранитный, 8 - габбро-гранитный, 9 - тоналит-гранодиоритовый, 10 - монцодиорит-гранитный, 11 - гнейсогранитный, 12 - неясной формационной принадлежности. Номера массивов на карте: 1 - Воронинский, 2 - Уйскоборский, 3 - Ахуново-Карагайский, 4 - Петропавловский, 5 - Заматохинско-Кассельский и Нижегородский, 6 - Верхнеуральский, 7 - Магнитогорская группа интрузий, 8 - Рассыпнянский, 9 - Карабулак-Разборненский, 10 - Чекинский, 11 Богдановский, 12 - Кацбахский 13 - Аргазинский, 14 - Челябинский, 15 - Ключевский, 16 - Варламовский, 17 - Коелгско-Кабанский и Пластовский, 18 - Борисовский, 19 - Уйский и Вандышевский, 20 - Санарский, 21 - Степнинский, 22 - Черноборский и Стрелецкий, 23 - Чернореченский, 24 - Чесменский, 25 - Джабыкский, 26 - Варшавский, 27 - Неплюевский, 28 - Суундукский, 29 - Толстинский. Структурные мегазоны: I - Восточно-Европейская платформа, II - Магнитогорская, III - Восточно-Уральская, IV - Зауральская.

Visean and acted in the Magnitogorsk-Bogdanovskiy graben [Salikhov et al., 2014] in the East Magnitogorsk zone (inset in Fig. 8). The activity propagated from the northern termination of the graben and was especially intense in the central and southern parts. Fissure eruptions in pull-apart basins produced volcanic cones or small edifices with multiple spatially close independent calderas. The Early Carboniferous volcanics belong to two chemically different complexes of Beryozovskiy $\left(\mathrm{C}_{1} \mathrm{t}_{2}-\mathrm{v}_{1}\right)$ and Grekhovskiy $\left(\mathrm{C}_{1} \mathrm{t}_{2}-\mathrm{v}_{2}\right)$. The Beryozovskiy complex consists mainly of subalkaline and less abundant alkaline low- or moderately-Ti basalts, basaltic andesites, and rhyodacites with partially preserved suprasubduction signatures (Fig. 9). The trace-element patterns show weak negative anomalies of $\mathrm{Nb}$ and $\mathrm{Ti}$ (0.71.9 wt. $\% \mathrm{TiO}_{2}$ in basalts), a still weaker $\mathrm{Zr}$ low, and positive anomalies in $\mathrm{U}, \mathrm{Th}, \mathrm{K}, \mathrm{Pb}$, or sometimes $\mathrm{Sr}$ and $\mathrm{Eu}$. The relatively low concentrations of Sr most likely indicate a particular non-arc type of volcanism in a setting different from that in the Devonian [Volynets et al., 1990]. The Beryozovskiy differentiated subalkaline volcanics are located mainly in the eastern side of a pull-apart basin in the East Magnitogorsk zone. The Grekhovskiy complex is dominated by within-plate subalkaline high-Ti basalts (Fig. 9) which may result from asthenospheric diapirism in the presence of a slab-tear [Kosarev et al., 2006]. They occur mostly in pull-apart basins, in the walls of collisional strike-slip faults in the East Magnitogorsk and East Ural zones.

The synchronous magmatic activity in the West Magnitogorsk zone produced conformal gabbro intrusions on the sides of large shallow synclinal folds. The rocks have the same subalkaline mafic chemistry as those in the neighbor Magnitogorsk-Bogdanovskiy graben. The Magnitogorsk gabbro-granite intrusions postdated the Early Visean volcanism and marked the onset of another tectonomagmatic event in the region. They are remarkable by combining within-plate and supra-subduction signatures [Fershtater, 2013] and by a depthward change in the shares of granites and gabbro: the former decrease while the latter increase. The gabbro host high-Ti magnetite mineralization (Maly Kuybas deposit in the Kuybas intrusion). The available 340$330 \mathrm{Ma}$ dates correspond to a Late Visean age of the activity [Ronkin et al., 2006].

A later magmatic event in the West Magnitogorsk zone produced a differentiated series of small picrodolerite intrusions with high-Ca tholeiite and calc-alkaline mafic compositions (Khudolaz complex) along a diagonal fault belt. The event spanned an interval of $328 \pm 0.5$ to $324 \pm 0.8 \mathrm{Ma}$ [Salikhov et al., 2012] within the Serpukhovian.

Thus, the magmatism in the West and East Magnitogorsk zones evolved from mafic to felsic compositions. This trend, as well as synchronicity with strike-slip faulting proven for some picrodolerite intrusions, is typical of mantle magmatism at transform boundaries associated with slab break off and asthenospheric diapirism [Martynov, Khanchuk, 2013]. The Visean-latest Permian transform motions in the South Ural accretionary-collisional system eventually led to accretion to the East European craton and complete consolidation. Magmatism within that period from 330 to $260 \mathrm{Ma}$ produced multiple gabbro-granite and granite intrusives of mantle-crust origin which have been comprehensively characterized in a number of previous publications [Tevelev, Kosheleva, 2002; Tevelev et al., 2006; Fershtater, 2013].

\section{DISCUSSION}

The reported data on the igneous complexes and related metallogeny of the region allow us to update the existing evolution models of the South Ural accretionary-collisional system. Unlike those models postulating predominant suprasubduction, collisional, and postcollisional magmatism [Tevelev, Kosheleva, 2002; Puchkov, 2003, 2010; Tevelev 
(a)

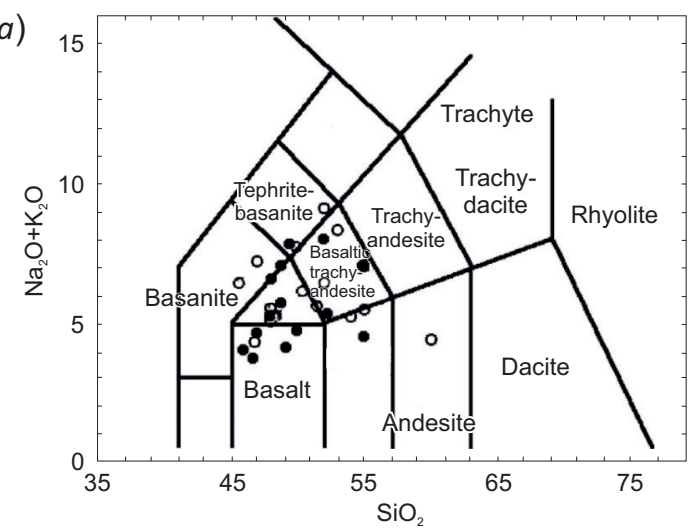

(c)

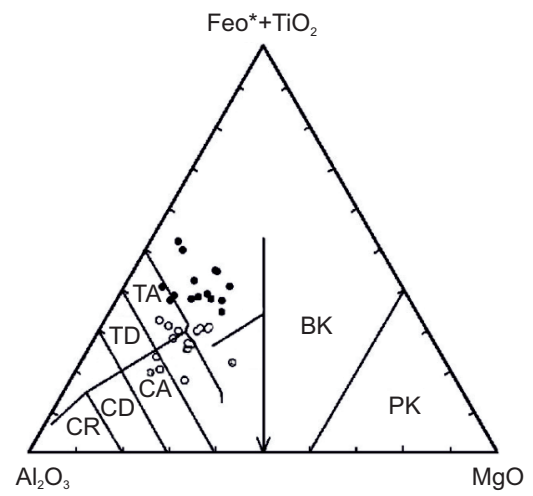

(e)

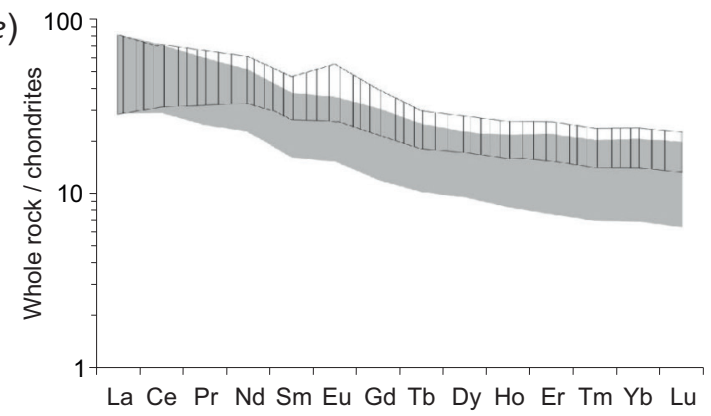

(b)

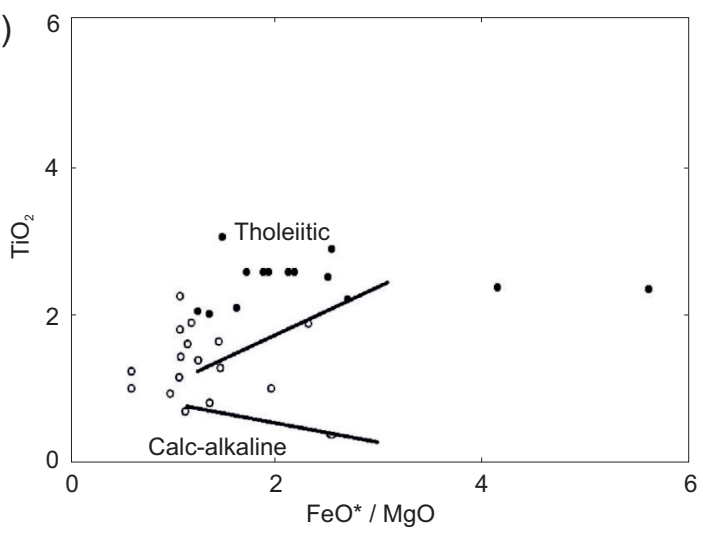

(d)

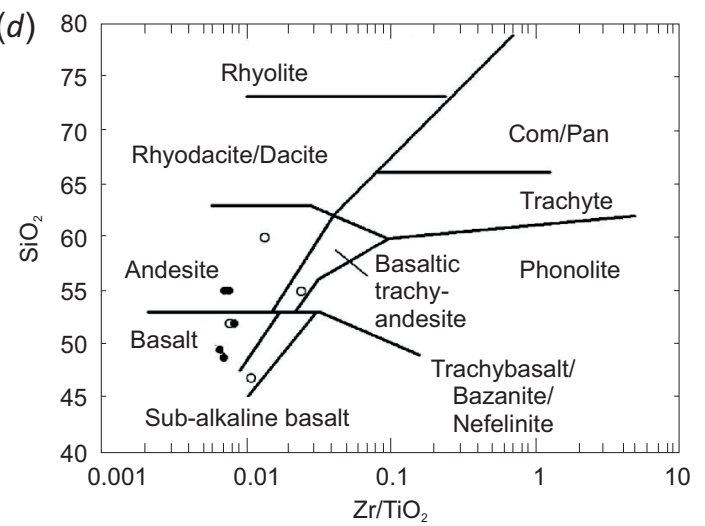

$(f)$

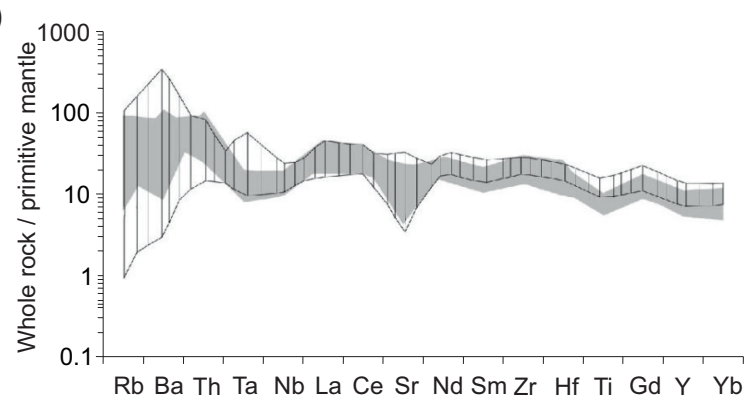

$\circ \square 1 \quad \bullet \square 2$

Fig. 9. Major and trace element signatures signatures of Early Carboniferous collisional basalts of the Magnitogorsk zone.

1 - Beryozovskiy differentiated basalt-andesite-dacite-rhyolite volcanic complex $\left(\mathrm{C}_{1} \mathrm{t}_{1}-\mathrm{t}_{2} \mathrm{~b}\right) ; 2$ - Grekhovskiy differentiated basaltandesite-dacite-rhyolite volcanic complex $\left(\mathrm{C}_{1} \mathrm{t}_{2}-\mathrm{v}_{1} \mathrm{~g}\right)$. Legend same as in Fig. 4.

Рис. 9. Геохимические характеристики базальтов раннекаменноугольного возраста, отвечающих коллизионной геодинамической обстановке (Магнитогорская мегазона).

1 - березовский дифференцированный базальт-андезит-дацит-риолитовый вулканический комплекс $\left(\mathrm{C}_{1} \mathrm{t}_{1}-\mathrm{t}_{2} \mathrm{~b}\right) ; 2$ - греховский дифференцированный базальт-андезит-дацит-риолитовый вулканический комплекс $\left(\mathrm{C}_{1} \mathrm{t}_{2}-\mathrm{v}_{1} \mathrm{~g}\right)$. Условные обозначения см. рис. 4.

et al., 2006; Fershtater et al., 2007; Fershtater, 2013], we additionally distinguish a setting of transform boundaries [Vladimirov et., 2020]. The transform boundary conditions left record in many similar structures of Asia: Early Cretaceous and Eocene geodynamic complexes in eastern Asia; Jurassic - Early Cretaceous complexes in the regions of Kolyma Loop, Mongolia-Okhotsk belt, and Transbaikalia; and Devonian to Permian complexes in the Altai region [Khanchuk et al., 1997, 2019; Martynov et al., 2002; Simanenko et al., 2006; Vladimirov et al., 2020; Martynov, Khanchuk, 2013; Kruk, 2015]. Rocks of this type have been exhaustively documented in California [Rogers et al., 1995]. The Californian slab-tear magmatism caused by ridge subduction has produced diverse complexes with mixed within-plate, suprasubduction, and mid-ocean ridge signatures that represent, respectively, the contributions of an asthenospheric diapir, a mantle wedge, and a slab to magma generation.

In the same way, the Middle-Late Devonian-Carboniferous Magnitogorsk and East Ural volcanoplutonic belts include flexure-like fold and fault structures and their rhombshaped fragments (Khudolaz, Mariinsk, Kumak, and Buruktal) that formed under a shear stress. These structures are 
described by K.P. Plyusnin [Plyusnin, 1971] and S.E. Znamensky [Znamensky, 2009], with Late Devonian $\left(D_{2-3}\right)$ and Early Carboniferous intrusions in their fragments, are prominent in the tectonic-paleovolcanic map of the South Urals (see Fig. 1) [Seravkin et al., 1992] and in the tectonic map of the Khudolaz area compiled by S. Znamenskiy [Znamensky, 2009]. The presence of VMS and porphyry $\mathrm{Cu}$ mineralization is consistent with features of cyclic volcanism and intrusive magmatism.

VMS deposits in the Magnitogorsk zone reside in the upper strata of the Buribay $\left(\mathrm{D}_{1} \mathrm{e}_{2}{ }^{1}\right)$, Upper Tanalyk $\left(\mathrm{D}_{1} \mathrm{e}_{2}{ }^{2}\right)$, Kiembay $\left(\mathrm{D}_{1} \mathrm{e}_{2}{ }^{1}\right)$, South Irendyk $\left(\mathrm{D}_{1} \mathrm{ef}_{1}{ }^{1}\right)$, Sukrak $\left(\mathrm{D}_{1} \mathrm{ef}_{1}{ }^{2}\right)$, Dzhusa $\left(\mathrm{D}_{1} \mathrm{ef}_{1}{ }^{1}\right)$, and Karamalytash $\left(\mathrm{D}_{1} \mathrm{ef}_{2}\right)$ volcanic complexes.

The suprasubduction volcanics prevailing in the Magnitogorsk zone coexist with non-arc basalts which are compositionally similar to within-plate oceanic flood basalts and hawaiites, with high to moderate Ti enrichment (1.44.86 wt. $\% \mathrm{TiO}_{2}$ ). However, the linkage to subduction attests to their origin from mantle diapirs in an arc system rather to than a plume (within-plate hotspot) origin. Diapirism can produce back-arc and arc spreading basins and is in some cases associated with slab tears. Basalts of this kind are, for instance, those with moderate Ti contents from the lower strata of the Buribay tholeiite-boninite arc complex $\left(\mathrm{D}_{1} \mathrm{e}_{2}\right)$ and from the Bolshoy Kumak complex lying over than Dzhusa $\left(D_{2} \mathrm{ef}_{1}\right)$, at the base of $\mathrm{D}_{2} \mathrm{ef}_{2}$ stratigraphic equivalents of the Karamalytash Fm. in the East Magnitogorsk zone. All these spreading zones most likely were genetically related to transform motions which, however, did not disturb much the steady subduction regime [Kosarev et al., 2014].

Porphyry $\mathrm{Cu}$ deposits occur in diorites that emplaced during the final phase of volcanoplutonic magmatism. The mineralization history comprised six events distinguished from data of isotope geochronology and metallogeny. They were, namely, three events of porphyry $\mathrm{Au}-\mathrm{Cu}$ mineralization: $429 \mathrm{Ma}\left(\mathrm{S}_{2}\right)$ North Tomino and Berezniki deposits in the East Ural volcanoplutonic belt, 412 Ma Voznesenka deposit and $418 \mathrm{Ma}\left(\mathrm{D}_{1}\right.$ eh-Pr) Karagaykul deposit in the Main Ural Fault, and 380 Ma Salavat deposit in the West Magnitogorsk zone; one event of porphyry $\mathrm{Cu}-\mathrm{Mo}$ mineralization: 360 Ma Upper Ural deposit in the East Magnitogorsk zone; and two events of porphyry (Mo)-Au-Cu mineralization in the East Ural volcanoplutonic belt: 356 Ma Mikheevka and $362 \mathrm{Ma}\left(\mathrm{D}_{3} \mathrm{fm}-\mathrm{C}_{1}\right)$ Tarutino deposits and $325 \mathrm{Ma}\left(\mathrm{C}_{1} \mathrm{sp}\right)$ Benkala deposit in the Valerianovka zone [Grabezhev, 2009; Kosarev et al., 2014].

Sm-Nd isotope systematics. The available Sm and Nd isotope data for the South Ural region (Fig. 10) show $\mathrm{T}_{\mathrm{Nd}}(\mathrm{DM}-2)$ model ages of granitoids from 0.7 to $1.0 \mathrm{Ga}$ in the Magnitogorsk zone and >1 Ga in the East Ural Uplift. The granitoids of the Magnitogorsk zone mostly fit into the isotope evolution of E-MORB and OIB basalts which indicates their origin mainly from juvenile crust. The granitic magma in the East Ural Uplift, on the contrary, bears signatures of old crustal material of uncertain origin that requires further investigation. Thus, the contribution of recycled crust to the source of granitic magma is the smallest in the Magnitogorsk zone and the greatest in the East Ural Uplift. The presence of Precambrian in the Suunduk-Chelyabinsk zone of the East Ural Uplift was assumed [Puchkov et al., 1986] by the development of granite-migmatite complexes and massifs of the granite formation, as well as by the early $\left(0-\mathrm{S}_{2}\right)$ manifestation of island-arc volcanism.

The Middle-Late Paleozoic geodynamic evolution scenario of the South Ural accretionary-collisional system was presumably as sketched in Fig. 11.

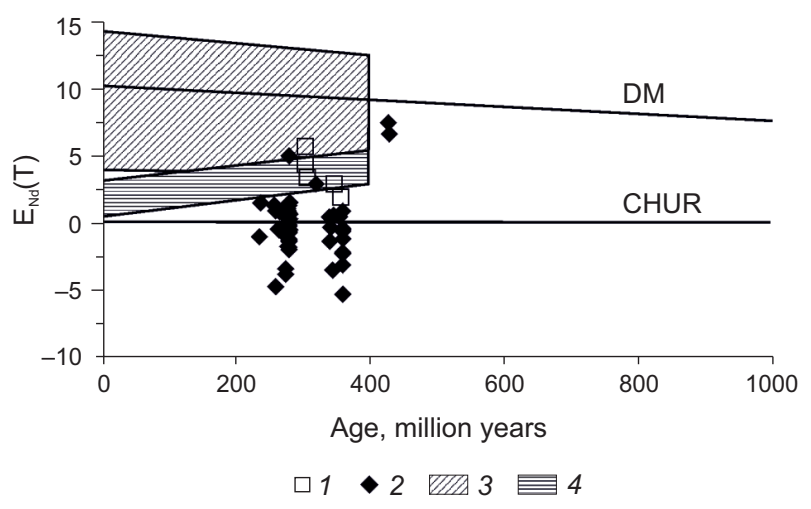

Fig. 10. Sm-Nd isotope systematics of granitoids and basement rocks in the South Ural accretionary-collisional system.

1, 2 - granitoids of South Urals: Magnitogorsk (1) and East Ural (2) zones [Osipova et al., 2008; Bea et al., 2005]; 3, 4 - oceanic basalts of South Urals: N-MORB (3), E-MORB and OIB (4) [Spadea et al., 2002]. The trends of depleted mantle (DM) and chondrite uniform reservoir (CHUR) are according to [Goldstein, Jacobsen, 1988] $\left({ }^{143} \mathrm{Nd} /{ }^{144} \mathrm{Nd}-0.513151,{ }^{147} \mathrm{Sm} /{ }^{144} \mathrm{Nd}-0.2136\right)$ and [Jacobsen, Wasserburg, 1984] $\left({ }^{143} \mathrm{Nd} /{ }^{144} \mathrm{Nd}-0.512638,{ }^{147} \mathrm{Sm} /{ }^{144} \mathrm{Nd}-0.1967\right)$, respectively.

Рис. 10. Соотношение изотопных характеристик Nd в гранитоидах и породах фундамента Южно-Уральской аккреционноколлизионной системы.

1-2 - гранитоиды Южного Урала: 1 - Магнитогорская мегазона, 2 -Восточно-Уральская зона [Osipova et al., 2008; Bea et al., 2005]; 3-4 - океанические базальты Южного Урала: 3 - N-MORB, 4 - E-MORB и OIB [Spadea et al., 2002]. Линия эволюции деплетированной мантии (DM) проведена по данным [Goldstein, Jacobsen, 1988] $\left({ }^{143} \mathrm{Nd} /{ }^{144} \mathrm{Nd}=0.513151,{ }^{147} \mathrm{Sm} /{ }^{144} \mathrm{Nd}=0.2136\right)$, линия эволюции единого хондритового резервуара (CHUR) - по данным [Jacobsen, Wasserburg, 1984] $\left({ }^{143} \mathrm{Nd} /{ }^{144} \mathrm{Nd}=0.512638\right.$, $\left.{ }^{147} \mathrm{Sm} /{ }^{144} \mathrm{Nd}=0.1967\right)$. 


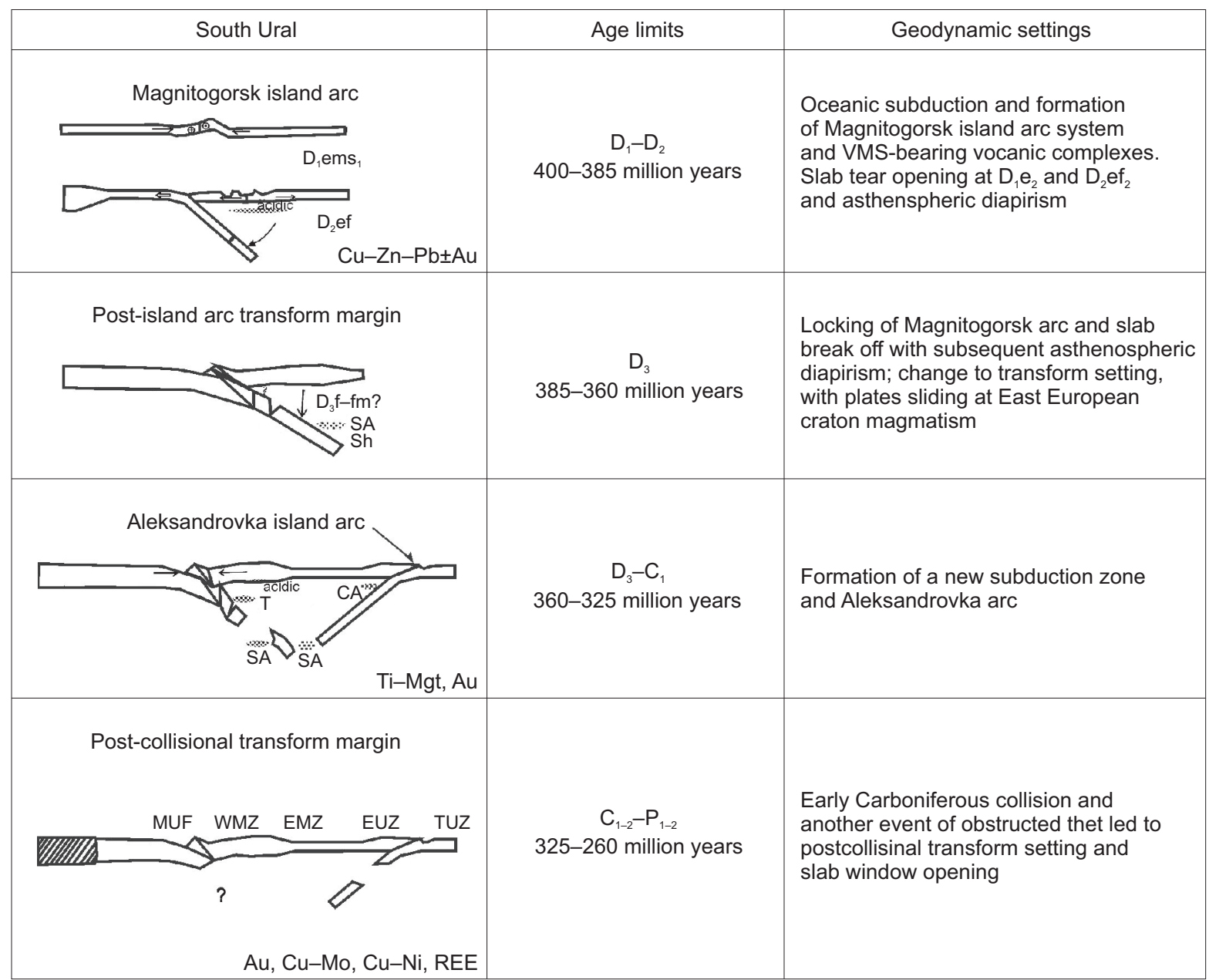

Fig. 11. Model of geodynamic and metallogenic events in the Devonian to Permian history of the South Ural accretionary-collisional system. Compiled by A.M. Kosarev, A.G. Vladimirov and A.I. Khanchuk.

Abbreviations stand for: SA - subalkaline, CA - calc-alkaline, Sh - shoshonitic, T - tholeiitic, MUF - Main Ural Fault; WMZ - West Magnitogorsk Zone; EMZ - East Magnitogorsk Zone; EUZ - East Ural Zone; TUZ - Trans-Ural Zone.

Рис. 11. Геодинамический сценарий и металлогеническая специализация Южно-Уральской аккреционно-коллизионной системы. Составлена А.М. Косаревым, А.Г. Владимировым и А.И. Ханчуком.

Сокращения. Серии: SA - субщелочная, CA - известково-щелочная, Sh - шошонитовая, T - толеитовая. Структурно-формационные зоны: MUF - Главный Уральский разлом, WMZ - Западно-Магнитогорская зона, EMZ - Восточно-Магнитогорская зона, EUZ - Восточно-Уральская зона, TUZ - Зауральская зона.

\section{CONCLUSIONS}

The results of the study lead to several main inferences.

1. The Middle-Late Paleozoic history of the South Ural region encompassed alternating subduction and transformcollisional events at the continent-ocean transition. The largest volumes of magma in the Magnitogorsk zone erupted in the Early and Middle Devonian in a subduction setting and partly resulted from slab-tear asthenospheric diapirism $\left(\mathrm{D}_{1} \mathrm{e}_{2}\right.$ and $\left.\mathrm{D}_{2} \mathrm{ef}_{2}\right)$. The presence of within-plate basalts in VMS complexes suggests their participation in the process of ore formation and petrogenesis as a catalyst. In the Late Devonian, the Magnitogorsk arc became blocked, and the subduction setting changed to that of transform boundaries with slab break off and asthenospheric diapirism.

2. The latest Devonian - earliest Carboniferous activity led to the formation of a new subduction zone dipping westward and the Aleksandrovka island arc. Another event of collision and obstructed subduction in the Early Carboniferous again created a transform setting with post-collisional sliding plate motions and slab tear magmatism. The magmatism produced alkaline gabbro-granite intrusives which host skarn magnetite and Ti-magnetite deposits $\left(\mathrm{C}_{1}\right)$. The transform setting remained predominant from the Early Carboniferous through Permian when Eurasia had completed its consolidation. Mineralization of that time span occurs as large gold deposits in $\mathrm{Cu}-\mathrm{Ni}$ picrodolerites $\left(\mathrm{C}_{1}\right)$ and Mo-W ores in granites $\left(\mathrm{P}_{1-2}\right)$.

\section{ACKNOWLEDGEMENTS}

We greatly appreciate valuable and encouraging discussions with V. Puchkov, G. Fershtater and Yu. Martynov.

The study was supported by grants $12-05-31470,14-05-$ 00747, 14-05-00712, and 14-05-20269-g from the Russian Foundation for Basic Research and grant 15-17-10010 from 
the Russian Science Foundation. It was carried out as part of several projects: ONZ-9.3, 27P of the Geoscience Department of the Russian Academy of Sciences; joint projects of the Siberian, Ural, and Far East Branches of the Russian Academy of Sciences and the Ufa Federal Research Centre (project 12-S-5-1022, IP 77 Magmatism, Metamorphism, and Mineral Potential of Altaides and Uralides and project 79 Magmatism and Metallogeny at Transform Plate Boundaries: Causes of Diversity and Evolution in Space and Time); Programs for Performance Progress of Tomsk and Bashkirian Universities. The work was performed within the program of the state task of the IG UFRC RAS (project 0246-20190078) and the state task of the IGG UB RAS (project AAAAA18-118052590029-6).

\section{REFERENCES}

Abdullin A.A. (Ed.), 1984. Geology and Mineral Resources of the Southeastern Turgay Trough and Northern Ulytau. Vol. 1. Nauka, Alma-Ata, 231 p. (in Russian) [Геология и полезные ископаемые юго-востока Тургайского прогиба и Северного Улытау / Ред. А.А. Абдулин. Алма-Ата: Наука, 1984. T. 1. 231 с.].

Anan'eva E.M., Zoloev K.K., Lutkov R.I., Ovchinnikov L.N., Popov B.A., Rapoport M.S., Rybalka V.M., 1996. Ore Deposits and Physical Fields of the Urals. Publishing House of the Ural Branch of RAS, Ekaterinburg, 295 p. (in Russian] [Ананьева Е.М., Золоев К.К., Лутков Р.И., Овчинников Л.Н., Попов Б.А., Рапопорт М.С., Рыбалка В.М. Рудные месторождения и физические поля Урала. Екатеринбург: Изд-во УрО РАН, 1996. 295 c.].

Bea F., Fershtater G.B., Montero P., Smirnov V.N., Molina Palma J.M., 2005. Deformation-Driven Differentiation of Granite Magma: The Stepninsk Pluton of the Uralides, Russia. Lithos 81 (1-4), 209-233. http://dx.doi.org/10.1016/j.lithos. 2004.10.004.

Berlyand N.G., 1982. Zoning of the Urals According to the Type of Deep Structure of the Earth's Crust. Soviet Geology 11, 79-89 (in Russian) [Берлянд Н.Г. Районирование Урала по типу глубинного строения земной коры // Советская геология. 1982. № 11. С. 79-89].

Berlyand N.G., 2007. Deep Structure of the Ural Lithosphere. VSEGEI Publishing House, Saint Petersburg, 255 p. (in Russian) [Берлянд Н.Г. Глубинное строение литосферы Урала. СПб.: Изд-во ВСЕГЕИ, 2007. 255 с.].

Berzin N.A., Coleman R.G., Dobretsov N.L., Zonenshain L.P., Xuchang X., Chang E.Z., 1994. Geodynamic Map of the Western Part of the Paleoasian Ocean. Russian Geology and Geophysics 35 (7), 3-20.

Bogatikov O.A., Tsvetkov A.A., 1988. Evolution of Island Arc Magmatism. Nauka, Moscow, 248 p. (in Russian) [Богатиков О.А., Цветков А.А. Магматическая эволюция островных дуг. М.: Наука, 1988. 248 с.].

Boynton W.V., 1984. Cosmochemistry of the Rare Earth Elements: Meteorite Studies. Rare Earth Element Geochemistry. Developments in Geochemistry 2, 63-114. https:// doi.org/10.1016/B978-0-444-42148-7.50008-3.

Chemenda A., Matte Ph., Sokolov V., 1997. A Model of Paleozoic Obduction and Exhumation of High-Pressure/Low
Temperature Rocks. Tectonophysics 276 (1-4), 217-227. https://doi.org/10.1016/S0040-1951(97)00057-7.

Crawford A.J., Falloon T.J., Green D.H., 1989. Classification, Petrogenesis and Tectonic Setting of Boninites. Unwin Human, London, 1-49.

Davies J.H., von Blanckenburg F., 1995. Slab Break off: A Model of Lithosphere Detachment and Its Test in the Magmatism and Deformation of Collisional Orogens. Earth and Planetary Science Letters 129 (1-4), 85-102. https://doi. org/10.1016/0012-821X(94)00237-S.

Dobretsov N.L., Borisenko A.S., Izokh A.E., Zhmodik S.M., 2010. A Thermochemical Model of Eurasian Permo-Triassic Mantle Plumes as Basis for Prediction and Exploration for $\mathrm{Cu}-\mathrm{Ni}-\mathrm{PGE}$ and Rare-Metal Ore Deposits. Russian Geology and Geophysics 51 (9), 903-924. https://doi.org/10.1016/ j.rgg.2010.08.002.

Dymkin A.M., 1966. Petrology and Genesis of the Turgay Magnetite Field. Nauka, Novosibirsk, 168 p. (in Russian) [Дымкин А.М. Петрология и генезис магнетитовых месторождений Тургая. Новосибирск: Наука, 1966. 168 с.].

Edwards R.L., Wasserburg C.J., 1985. The Age and the Emplacement of Obducted Oceanic Crust in the Urals from Sm-Nd Systematics. Earth and Planetary Science Letters 72 (4), 389-404. https://doi.org/10.1016/0012-821X(85) 90060-3.

Ermolaeva G.M. (Ed.), 2001. Deep Structure and Geodynamics of the South Urals. Uralseis-95 Project. GERS, Tver, 250 p. (in Russian) [Глубинное строение и геодинамика Южного Урала (Проект Урсейс-95) / Ред. Г.М. Ермолаева. Тверь: ГЕРС, 2001. 250 с.].

Fershtater G.B., 2013. Paleozoic Intrusive Magmatism of the Middle and South Urals. Publishing House of the Ural Branch of RAS, Ekaterinburg, 365 p. (in Russian) [Ферштатер Г.Б. Палеозойский интрузивный магматизм Среднего и Южного Урала. Екатеринбург: Изд-во УрО РАН, 2013.365 c.].

Fershtater G.B., 2015. Early-Devonian Intrusive Magmatism of the Urals as Indicator Critical Stage Paleozoic History Mobile Belt. Lithosphere 5, 5-29 (in Russian) [Ферштатер Г.Б. Раннедевонский интрузивный магматизм Урала - индикатор переломного этапа в палеозойской истории подвижного пояса // Литосфера. 2015. № 5. C. 5-29].

Fershtater G.B., Kholodnov V.V., Kremenetsky A.A., Krasnobaev A.A., Borodina N.S., Zinkova E.A., Pribavkin S.V., 2010. Au-Bearing Gabbro-Tonalite-Granodiorite-Granite Plutons of the Urals: Age, Geochemistry, and Magmatic and Ore Evolution. Geology of Ore Deposits 52, 58-76. https://doi.org/ 10.1134/S107570151001006X.

Fershtater G.B., Krasnobaev A.A., 2007. Obduction Magmatism and Accompanied Migmatization (on the Example of the Urals). Lithosphere 3, 12-34 (in Russian) [Ферштатер Г.Б., Краснобаева А.А. Обдукционный магматизм и сопряженная мигматизация (на примере Урала) // Литосфера. 2007. № 3. C. 12-34].

Fershtater G.B., Krasnobaev A.A., Borodina N.S., Bea F., Montero P., 2007. Geodynamic Settings and History of the Paleozoic Intrusive Magmatism of the Central and Southern 
Urals: Results of Zircon Dating. Geotectonics 41 (6), 465486. https://doi.org/10.1134/S0016852107060039.

Gas'kov I.V., 2015. Specific Features of Pyrite Ore-Magmatic Systems Development in the Island Arc Environments of Rudny Altai and Southern Urals. Lithosphere 2, 17-39 (in Russian) [Гаськов И.В. Особенности развития колчеданных рудно-магматических систем в островодужных обстановках Рудного Алтая и Южного Урала // Литосфера. 2015. № 2. С. 17-39].

Goldstein S.J., Jacobsen S.B., 1988. Nd and Sr Isotopic Systematics of River Water Suspended Material: Implications for Crustal Evolution. Earth and Planetary Science Letters 87 (3), 249-265. https://doi.org/10.1016/0012-821X (88)90013-1.

Golovanova I.N., 2005. Thermal Field of the South Urals. Nauka, Moscow, 189 p. (in Russian) [Голованова И.В. Тепловое поле Южного Урала. М.: Наука, 2005. 189 с.].

Grabezhev A.I., 2009. Sr-Nd-C-O-H-S Isotope-Geochemical Description of South Urals Porphyry-Copper Fluid-Magmatic Systems: Probable Sources of Matter. Lithosphere 6, 66-89 (in Russian) [Грабежев A.И. Sr-Nd-C-O-H-S изотопно-геохимическая характеристика медно-порфировых флюидно-магматических систем Южного Урала: вероятные источники вещества // Литосфера. 2009. № 6. C. 66-89].

Grabezhev A.I., 2014. Novonikolaevsk (Mo, Au)-Cu-Porphyry Ore Area (Southern Ural, Russia): Petrogeochemistry of Orebearing Granitoids and Metasomatites. Lithosphere 2, 60-76 (in Russian) [Грабежев А.И. Новониколаевский (Mo, Au)-Cu-порфировый рудный узел (Южный Урал): Петрохимия рудоносных гранитоидов и метасоматитов // Литосфера. 2014. № 2. С. 60-76].

Grabezhev A.I., Ronkin Y.L., 2011. U-Pb of Zircons from Ore-Bearing Granitoids of the South Urals Porphyry-Copper Deposits. Lithosphere 3, 104-116 (in Russian) [Грабежев А.И., Ронкин Ю.Л. U-Рb возраст цирконов из рудоносных гранитоиодов медно-порфировых месторождений Южного Урала // Литосфера. 2011. № 3. С. 104-116].

Jacobsen S.B., Wasserhurg G.J., 1984. Sm-Nd Evolution of Chondrites and Achondrites. Earth and Planetary Science Letters 67, 137-150. https://doi.org/10.1016/0012-821X (84)90109-2.

Jensen S.A., 1976. New Cation Plot for Classifying Subalkalic Volcanic Rocks. Ontario Geological Survey Miscellaneous Paper 66, 22 p.

Jonas P., 2004. Tectonostratigraphy of Oceanic Crustal Terrains Hostihg Serpentinite - Associated Massive Sulfide Deposits in the Main Uralian Fault Zone (South Urals). Freiberg, $123 \mathrm{p}$.

Khain V.E., Tychkov S.A., Vladimirov A.G., 1996. Collision Orogeny: A Model for the Detachment of a Subducted Oceanic Lithosphere Plate as a Result of Continental Collision. Russian Geology and Geophysics 37 (1), 3-14.

Khanchuk A.I., Golozubov V.V., Martynov Yu.A., Simanenko V.P., 1997. Early Cretaceous and Paleogene Transform Continental Margins (Californian type) of the Russian Far East. In: Tectonics of Asia. Program and Theses of the XXX Tectonic Meeting (January 1 - December 31, 1997). GEOS, Moscow,
240-243 (in Russian) [Ханчук А.И., Голозубов В.В., Мартынов Ю.А., Симаненко В.П. Раннемеловая и палеогеновая трансформные континентальные окраины (калифорнийский тип) Дальнего Востока России // Тектоника Азии: Программа и тезисы XXX тектонического совещания (1 января - 31 декабря 1997 г.). М.: ГЕОС, 1997. C. 240-243].

Khanchuk A.I., Grebennikov A.V., Ivanov V.V., 2019. AlbianCenomanian Marginal Continental Orogenic Belt and the Magmatic Province of Pacific Asia. Russian Journal of Pacific Geology 38 (3), 4-29 (in Russian) [Ханчук А.И., Гребенников А.В., Иванов В.В. Альб-сеноманские окраинно-континентальный орогенный пояс и магматическая провинция Тихоокеанской Азии // Тихоокеанская геология. 2019. Т. 38. № 3. С. 4-29]. https://doi.org/10.30911/ 0207-4028-2019-38-3-4-29.

Kondiajn O.A. (Ed), 2011. The Urals. In: Geology and Mineral Resource of Russia. West of Russia and Ural. Vol. 1. Book 2. VSEGEI Publishing House, Saint Petersburg, 584 p. (in Russian) [Урал // Геология и полезные ископаемые России: Запад России и Урал / Ред. О.А. Кондиайн. СПб.: Изд-во ВСЕГЕИ, 2011. Т. 1. Кн. 2. 584 с.].

Kontar' E.S., Libarova L.E., 1997. Metallogeny of Copper, Zinc, Lead in the Urals. Uralgeolkom Publishing House, Ekaterinburg, 233 p. (in Russian) [Контарь Е.С., Либарова Л.Е. Металлогения меди, цинка, свинца на Урале. Екатеринбург: Изд-во Уралгеолком, 1997. 233 с.].

Kosarev A.M., Puchkov V.N., Ronkin Yu.L., Seravkin I.B., Kholodnov V.V, Grabezhev A.I., 2014. New Data on the Age and Geodynamic Position of Copper-Porphyry Mineralization in the Main Uralian Fault Zone (South Urals). Doklady Earth Sciences 459, 1317-1321. https://doi.org/10.1134/ S1028334X1411004X.

Kosarev A.M., Puchkov V.N., Seravkin I.B., 2005. Petrological-Geochemical Features of the Early Devonian-Eifelian Island Arc Volcanites of the Magnitogorsk Zone in a Geodynamic Context. Lithosphere 4, 22-41 (in Russian) [Koсарев А.М., Пучков В.Н., Серавкин И.Б. Петролого-геохимические особенности раннедевонско-эйфельских островодужных вулканитов магнитогорской зоны в геодинамическом контексте // Литосфера. 2005. № 4. C. 22-41].

Kosarev A.M., Puchkov V.N., Seravkin I.B., 2006. PetroGeochemical Features of Middle Devonian Early Carboniferous Island Arc and Collision Volcanites of the Magnitogorsk Zone in the Geodynamic Context. Lithosphere 1, 3-21 (in Russian) [Косарев A.М., Пучков В.Н., Серавкин И.Б. Петролого-геохимические особенности среднедевонско-раннекаменноугольных островодужных и коллизионных вулканитов магнитогорской зоны в геодинамическом контексте // Литосфера. 2006. № 1. С. 3-21].

Kosarev A.M., Puchkov V.N., Seravkin I.B., 2010. Pyrite Potential of the Southern Urals: Correlation of $\mathrm{Cu}$ and $\mathrm{Zn} \mathrm{Re}-$ sources with Geochemical Characteristics of Basalts of Ore Regions. Doklady Earth Sciences 435, 1633-1636. https:// doi.org/10.1134/S1028334X10120172.

Krasnobaev A.A., Davydov V.A., Cherednichenko N.V., 1998a. Zircon Geochronology of the Ilmenogorsk Formation 
and Some Geological Consequences. In: Yearbook 1997. Publishing House of IGG UB RAS, Ekaterinburg, 57-160 (in Russian) [Краснобаев А.А., Давыдов В.А., Чередниченко Н.В. Цирконовая геохронология ильменогорской свиты и некоторые геологические следствия // Ежегодник-1997. Екатеринбург: Изд-во ИГГ УрО РАН, 1998. C. 157-160].

Krasnobaev A.A., Kuznetsov G.P., Davydov V.A., 1998b. The Age and Origin of the Chelyabinsk Complex Gneisses. Doklady Earth Sciences 360 (4), 586-589.

Kruk N.N., 2015. Continental Crust in Gorny Altai: Stages of Formation and Evolution; Indicative Role of Granitoids. Russian Geology and Geophysics 56 (8), 1097-1113. https:// doi.org/10.1016/j.rgg.2015.07.001.

Kuzmin M.I., 1985. Geochemistry of Magmatic Rocks of Phanerozoic Mobile Belts. Nauka, Novosibirsk, 199 p. (in Russian) [Кузьмин М.И. Геохимия магматических пород фанерозойских подвижных поясов. Новосибирск: Наука, 1985. 199 с.].

Le Maitre R.W. (Ed.), 1989. A Classification of Igneous Rocks and Glossary of Terms: Recommendations of the International Union of Geological Sciences, Subcommission on the Systematics of Igneous Rocks. Blackwell, Oxford, $193 \mathrm{p}$.

Martynov Yu.A., Chaschin A.A., Rasskazov S.V., Saranina E.V., 2002. Late Miocene-Pliocene Basalt Volcanism in the South of the Russian Far East as an Indicator of the Heterogeneity of the Lithospheric Mantle in the ContinentOcean Transition Zone. Petrology 10 (2), 189-209 (in Russian) [Мартынов Ю.А., Чащин А.А., Рассказов С.В., Саранина Е.В. Позднемиоцен-плиоценовый базальтовый вулканизм юга Дальнего Востока России как индикатор гетерогенности литосферной мантии в зоне перехода континент-океан // Петрология. 2002. Т. 10. № 2. C. 189-209].

Martynov Yu.A., Khanchuk A.I., 2013. Cenozoic Volcanism of the Eastern Sikhote Alin: Petrological Studies and Outlooks. Petrology 21, 85-99. https://doi.org/10.1134/ S0869591113010049.

Maslennikov V.V., 1999. Sedimentogenesis, halmyrolysis and ecology of massive sulphide-bearing paleohydrothermal fields (after example of the South Ural). The scientific edition. Geotur, Miass, 348 p. (in Russian) [Масленников В.В. Седиментогенез, гальмиролиз и экология колчеданоносных палеогидротермальных полей (на примере Южного Урала). Миасс: Геотур, 1999. 348 с.].

Maslov V.A., Artyushkova O.V., 2010. Stratigraphy and Correlation of Devonian Sedimentary Rocks in the Magnitogorsk Megazone of the Southern Urals. DizaynPoligrafServis, Ufa, 288 р. (in Russian) [Маслов В.А., Артюшкова О.В. Стратиграфия и корреляция девонских отложений Магнитогорской мегазоны Южного Урала. Уфа: ДизайнПолиграфСервис, 2010. 288 с.].

Maslov V.A., Cherkasov V.L., Tishchenko V.T., Smirnova I.A., Artyushkova O.V., Pavlov V.V., 1993. Volcanic Complexes and Main $\mathrm{Cu}$-VMS Fields of the South Urals: Stratigraphy and Correlations. Publishing House of the Ufa Federal Research Centre RAS, Ufa, 216 p. (in Russian) [Маслов В.А.,
Черкасов В.Л., Тищенко В.Т., Смирнова И.А., Артюшкова О.В., Павлов В.В. Стратиграфия и корреляция среднепалеозойских вулканогенных комплексов основных медноколчеданных районов Южного Урала. Уфа: Издво УФИЦ РАН, 1993. 216 с.].

Melcher F., Grum W., Thalhammer T.V., Thalhammer O.A.R., 1999. The Giant Chromite Deposits at Kempirsai, Urals: Constraints from Trace Element (PGE, REE) and Isotope Data. Mineralium Deposita 34, 250-272. https://doi.org/10.10 07/s001260050202.

Melekestseva I.Yu., 2007. Heterogeneous Cobalt-Copperpyritic Deposits in the Ultramafites of the Paleoisland-Arch Structures. Nauka, Moscow, 245 p. (in Russian) [Мелекесцева И.Ю. Гетерогенные кобальт-медноколчеданные месторождения в ультрамафитах палеоостроводужных структур. М.: Наука, 2007. 245 с.].

Miyashiro A., 1974. Volcanic Rock Series in Island Arcs and Active Continental Margins. American Journal of Science 274 (4), 321-355. https://doi.org/10.2475/ajs.27 4.4.321.

Nimis P., Omenetto P., Buschmann B., Jonas P., Simonov V.A., 2010. Geochemistry of Igneous Rocks Associated with Ultramafic-Mafic-Hosted Cu (Co, Ni, Au) VMS Deposits from the Main Uralian Fault (Southern Urals, Russia). Mineralogy and Petrology 100, 201-214. https://doi.org/10.1007/s0 0710-010-0134-6.

Osipova T.A., Tevelev A.V., Popov V.S., Belyatsky B.V., 2008. Sm-Nd and Rb-Sr Age of Gabbroic Rocks in the Dzhabyk Batholith, the Southern Urals. Doklady Earth Sciences 419, 275-280. https://doi.org/10.1134/S1028334X08020190.

Pavlov N.V., Kravchenko G.G., Chuprynina I.I., 1968. Chromites of the Kempirsay Pluton. Nauka, Moscow, 197 p. (in Russian) [Павлов Н.В., Кравченко Г.Г., Чупрынина И.И. Хромиты Кемпирсайского плутона. М.: Наука, 1968. 197 с.].

Pearce J.A., Lippard S.J., Roberts S., 1984. Characteristics and Tectonic Significance of Supra-Subduction Zone Ophiolites. In: B.P. Kokelaar, M.F. Howells (Eds), Marginal Basin Geology. Geological Society of London Special Publications 16, 77-94. https://doi.org/10.1144/GSL.SP.1984.016.01.06.

Peive A.V., Ivanov S.N., Porfilaev A.S., Necheukhin V.M., 1977. Tectonics of Urals. Explanatory Note to the Tectonic Map of the Urals at a Scale of 1:1000000. Nauka, Moscow, 124 p. (in Russian) [Пейве А.В., Иванов С.Н., Порфилаев А.С., Нечеухин В.М. Тектоника Урала: Объяснительная записка к тектонической карте Урала масштаба 1:1000000. М.: Наука, 1977. 124 с.].

Perevozchikov B.V., 2011. Tectonic Position of ChromiteBearing Basite-Ultrabasite Complexes of the Urals. Lithosphere 4, 93-109 (in Russian) [Перевозчиков Б.В. Тектоническая позиция хромитоносных базит-ультрабазитовых комплексов Урала // Литосфера. 2011. № 4. C. 93-109].

Perfil'ev F.S., 1979. Formation of the Earth's Crust of the Ural Geosyncline. Proceedings of the Geological Institute of the USSR Academy of Science. Iss. 328. Nauka, Moscow, 188 p. (in Russian) [Перфильев Ф.С. Формирование земной коры Уральской геосинклинали // Труды ГИН АН СССР. М.: Наука, 1979. Вып. 328. 188 с.]. 
Plyusnin K.P., 1971. Method for Studying the Tectonic Structures in Fond Belts: Case Study of the Urals. Perm, 217 p. (in Russian) [Плюснин К.П. Методика изучения тектонических структур складчатых поясов (на примере Урала). Пермь, 1971. 217 с.].

Poltavets Yu.A., 2009. Tyumen-Kustanai Trough: The Magmatism and Metallogeny Features. Lithosphere 3, 1432 (in Russian) [Полтавец Ю.А. Тюменско-Кустанайский прогиб: особенности магматизма и металлогении // Литосфера. 2009. № 3. С. 14-32].

Poltavets Yu.A., Dymkin A.M., Baklaev Ya.P., Poltavets Z.I., 1988. Metallogeny of Skarn Magnetite Deposits of the Urals. In: Metallogeny and Mineral Potential of the Urals. Collection of Scientific Papers. Publishing House of the Ural Branch of the USSR Academy of Sciences, Sverdlovsk, 73-86 (in Russian) [Полтавец Ю.А., Дымкин А.М., Баклаев Я.П., Полтавец 3.И. К металлогении скарново-магнетитовых месторождений Урала // Рудоносные и рудные формации Урала: Сборник научных трудов. Свердловск: Изд-во Ур0 АН СССР, 1988. С. 73-86].

Prokin V.A., Buslaev F.P., Ismagilov M.I., Necheukhin V.M., Popov V.A., Yazeva R.G., Yurish V.V., Lyadsky P.V. et al., 1988. $\mathrm{Cu}$-Volcanic Massive Sulfide Deposits in the Urals: Local Geology. Publishing House of the Ural Branch of the USSR Academy of Sciences, Sverdlovsk, 241 p. (in Russian) [Прокин В.А., Буслаев Ф.П., Исмагилов М.И., Нечеухин В.М., Попов В.А., Язева Р.Г., Юриш В.В., Лядский П.В. и др. Медноколчеданные месторождения Урала: Геологические строение. Свердловск: Изд-во УрО АН СССР, 1988. 240 c.].

Prokin V.A., Necheukhin V.M., Sopko P.F. et al., 1985. CuVolcanic Massive Sulfide Deposits in the Urals: Geological Constraints. Publishing House of the Ural Scientific Centre of the USSR Academy of Sciences, Sverdlovsk, 288 p. (in Russian) [Прокин B.A., Нечеухин В.М., Сопко П.Ф. и др. Медноколчеданные месторождения Урала: Геологические условия. Свердловск: Изд-во УНЦ АН СССР, 1985. 288 c.].

Puchkov V.N., 1993. Paleooceanic Structures of the Urals. Geotectonics 3, 18-33 (in Russian) [Пучков В.Н. Палеоокеанические структуры Урала // Геотектоника. 1993. № 3. C. 18-33].

Puchkov V.N., 1996. Geodynamic Control of Metamorphism in the Urals. Geotectonics 2, 16-33 (in Russian) [Пучков В.Н. Геодинамический контроль метаморфизма на Урале // Геотектоника. 1996. № 2. С. 16-33].

Puchkov V.N., 2000. Paleogeodynamics of the Southern and Middle Urals. Gilem, Ufa, 146 p. (in Russian) [Пучков В.Н. Палеогеодинамика Южного и Среднего Урала. Уфа: Гилем, 2000. 146 с.].

Puchkov V.N., 2003. Uralides and Timanides: Their Structural Relationship and Position in the Geologic History of the Ural-Mongolian Fold Belt. Russian Geology and Geophysics 44 (1-2), 27-38.

Puchkov V.N., 2010. Geology of the Urals and Cis-Urals (Actual Problems of Stratigraphy, Tectonics, Geodynamics and Metallogeny). DizaynPoligrafServis, Ufa, 280 p. (in Russian) [Пучков В.Н. Геология Урала и Приуралья (актуальные вопросы стратиграфии, тектоники, геодинамики и металлогении). Уфа: ДизайнПолиграфСервис, 2010. 280 с.].

Puchkov V.N., Ivanov K.S., 1985. First Information about Volcanogenic-Siliceous Strata in the East of the Urals. Doklady of the USSR Academy of Sciences 285 (4), 966-970 (in Russian) [Пучков В.Н., Иванов К.С. Первые сведения о вулканогенно-кремнистых толщах на востоке Урала // Доклады АН СССР. 1985. Т. 285. № 4. С. 966-970].

Puchkov V.N., Svetlakova A.N., 1993. The Structure of the Urals along the Trinity Profile. Doklady of the USSR Academy of Sciences 333 (3), 348-351.

Puchkov V.N., Rapoport M.S., Fershtater G.B., Anan'eva E.M., 1986. Tectonic Control of the Paleozoic Granite Magmatism in the Eastern Slope of the Urals. In: Research on the Petrology and Metallogeny of the Southern Urals. Publishing House of IGG USC of the USSR Academy of Sciences, Sverdlovsk, 85-95. [Пучков В.Н., Рапопорт M.C., Ферштатер Г.Б., Ананьева Е.М. Тектонический контроль палеозойского гранитоидного магматизма на восточном склоне Урала // Исследования по петрологии и металлогении Урала. Свердловск: Изд-во ИГГ УНЦ АН СССР, 1986. С. 85-95].

Pushkarev E.V., Gottman I.A., Kosarev A.M., 2013. Ankaramite of the Irendyk Formation, South Urals: Petrology and Genesis. In: Volcanic Massive Sulfide Deposits: Geology, Exploration, Mining and Ore. V Readings in Memory S.N. Ivanov. Proceedings of the All-Russia Scientific Conference (October 1-5, 2013). Publishing House of IGG UB RAS, Ekaterinburg, 118-120 (in Russian) [Пушкарев E.A., Готтман И.А., Косарев А.М., 2013. Анкарамиты ирендыкской свиты Южного Урала: петрология и генезис // V чтения памяти С.Н. Иванова: Колчеданные месторождения - геология, поиски, добыча и переработка руд: Материалы Всероссийской научной конференции (15 октября 2013 г.). Екатеринбург: Изд-во ИГГ УрО РАН, 2013. C. 118-120].

Rilkov S.A., Rybalka A.V., Ivanov K.S., 2013. Deep Structure and Metallogeny of the Urals: The Comparison of Deep Structure of Southern, Middle and Polar Urals. Lithosphere 1, 3-16 (in Russian) [Рыльков С.А., Рыбалка А.В., Иванов К.С. Геологическое строение и металлогения Урала: сопоставление глубинной структуры Южного, Среднего и Полярного Урала // Литосфера. 2013. № 1. С. 3-16].

Rogers N.W., Hawkesworth C.J., Osmerod D.S., 1995. Late Cenozoic Basaltic Magmatism in the Western Great Basin, California and Nevada. Journal of Geophysical Research: Solid Earth 100 (B7), 10287-10301. https://doi.org/10. 1029/94JB02738.

Romanov V.A., 1985. Tectonics of the Magnitogorsk Megasynclinorium. Publishing House of the Bashkir Branch of the USSR Academy of Sciences, Ufa, 112 p. (in Russian) [Романов В.А. Тектоника Магнитогорского мегасинклинория. Уфа: Изд-во БФ АН СССР, 1985. 112 с].

Ronkin Yu.L., Semenov I.V., Lepikhina O.P., Popova O.Yu., 2006. Intrusions in the Magnitogorsk Early Carboniferous Rift Structure: Sr-Nd Isotope Constraints. In: Yearbook 2005. Publishing House of IGG UB RA, Yekaterinburg, 314-318 (in Russian) [Ронкин Ю.Л., Семенов И.В., Лепихина О.П., 
Попова О.Ю. Интрузивы Магнитогорской раннекаменноугольной рифтогенной структуры: Sr-Nd изотопные ограничения // Ежегодник-2005. Екатеринбург: Издво ИГГ УрО РАН, 2006. С. 314-318].

Ryazantsev A.V., Borisenok D.V., Dubinina S.V., Kalinina E.A., Kuznetsov N.B., Matveeva E.A., Aristov V.A., 2005. Structure of the Sakmar Zone in the South Urals in the Mednogorsk VMS Field. In: Treatise on Regional Tectonics. South Urals. Vol. 1. Nauka, Moscow, 84-132 (in Russian) [Рязанцев А.В., Борисенок Д.В., Дубинина С.В., Калинина Е.А., Кузнецов Н.В., Матвеева Е.А., Аристов В.А. Общая структура Сакмарской зоны Южного Урала в районе Медногорских колчеданных месторождений // Очерки по региональной тектонике: Южный Урал. М.: Наука, 2005. T. 1. C. 84-132].

Salikhov D.N., Belikova G.I., Puchkov V.N., Ernst R., Sederlund U., Kamo S., Rakhimov I.R., Kholodnov V.V., 2012. A Nickel-Bearing Intrusive Complex in Southern Urals. Lithosphere 6, 66-72 (in Russian) [Салихов Д.Н., Беликова Г.И., Пучков В.Н., Эрнст Р., Седерлунд У., Камо С., Рахимов И.Р., Холоднов В.В. Никеленосный интрузивный комплекс на Южном Урале // Литосфера. 2012. № 6. С. 66-72].

Salikhov D.N., Mitrofanov V.A., 1994. Upper Devonian-Lower Carboniferous Intrusive Magmatism of the Magnitogorsk Basin (South Urals). Publishing House of the Ufa Scientific Centre of RAS, Ufa, 142 p. (in Russian) [Салихов Д.Н., Митрофанов В.А. Интрузивный магматизм верхнего девона нижнего карбона Магнитогорского магасинклинория (Южный Урал). Уфа: Изд-во УНЦ РАН, 1994. 142 с.].

Salikhov D.N., Moseychuk V.M., Kholodnov V.V., Rakhimov I.R., 2014. Carboniferous Intrusive-Volcanic Magmatism of Magnitogorsk-Bogdanovskiy Graben in the Light of New Geological and Geochemical Data. Lithosphere 5, 33-56 (in Russian) [Салихов Д.Н., Мосейчук В.М., Холоднов В.В., Рахимов И.Р. Каменноугольный вулкано-интрузивный магматизм Магнитогорско-Богдановского грабена в свете новых геолого-геохимических данных // Литосфера. 2014. № 5. С. 33-56].

Samygin S.G., Fedotova A.A., Bibikova E.V., Karyakin Y.V., 2007. Vendian Suprasubduction Volcanism in the Uraltau Tectonic Zone (South Urals). Doklady Earth Sciences 416, 995-999. https://doi.org/10.1134/S1028334X07070033.

Semenov I.V., 2000. Paleooceanic Spreading Volcanism in the Urals: Implications for the Parameters of the Paleozoic Ural Ocean. Publishing House of the Ural Branch of RAS, Ekaterinburg, 362 p. (in Russian) [Семёнов И.В. Палеоокеанический спрединговый вулканизм Урала и реконструкция параметров Уральского палеозойского океана. Екатеринбург: Изд-во УрО РАН, 2000. 362 с.].

Şengör A.M.C., Natal'in B.A., Burtman V.S., 1993. Evolution of the Altaid Tectonic Collage and Paleozoic Crustal Growth in Eurasia. Nature 364, 299-307. https://doi.org/ 10.1038/364299a0.

Seravkin I.B., 1997. Tectonic-Magmatic Zoning of the Southern Urals and Its Position in the Folded Systems of the Ural-Mongol Belt. Geotectonics 1, 32-47 (in Russian) [Серавкин И.Б. Тектоно-магматическая зональность Южного Урала и его положение в складчатых системах
Урало-Монгольского пояса // Геотектоника. 1997. № 1. C. 32-47].

Seravkin I.B., 2007. Volcanogenic Massive Sulfide Deposits of the Southern Urals. In: N.P. Jushkin, V.N. Sazonov (Eds), Geodynamics, Magmatism, Metamorphism, and Ore Formation. Collection of Scientific Papers. Publishing House of IGG UB RAS, Ekaterinburg, 638-669 (in Russian) [Серавкин И.Б. Вулканогенные колчеданные месторождения Южного Урала // Геодинамика, магматизм, метаморфизм и рудообразование: Сборник научных трудов / Ред. Н.П. Юшкин, В.Н. Сазонов. Екатеринбург: Изд-во ИГГ УрО РАН, 2007. С. 638-669].

Seravkin I.B., 2010. Metallogeny of the South Urals and Central Kazakhstan. Gilem, Ufa, 284 p. (in Russian) [Серавкин И.Б. Металлогения Южного Урала и Центрального Казахстана. Уфа: Гилем, 2010, 284 с.].

Seravkin I.B., Kosarev A.M., Salikhov D.N., Znamensky S.E., Rodicheva Z.I., Rykus M.V., Snachev V.I., 1992. Volcanism of the South Urals. Nauka, Moscow, 197 p. (in Russian) [Ceравкин И.Б., Косарев А.М., Салихов Д.Н., Знаменский С.Е., Родичева 3.И., Рыкус М.В., Сначев В.И. Вулканизм Южного Урала. М.: Наука, 1992. 197 с.].

Seravkin I.B., Tsvetkova A.A., 1982. Structure of the Magnitogorsk Megasynclinorium in the Light of Palaeovolcanic Reconstructions and Geophysical Data. In: Volcanism and Ore Formation of the Urals. Publishing House of the Bashkir Branch of the USSR Academy of Sciences, Ufa, 19-32 (in Russian) [Серавкин И.Б., Цветкова А.А. Строение Магнитогорского мегасинклинория в свете палеовулканологических реконструкций и геофизических данных // Вулканизм и рудообразование Урала. Уфа: БФ АН СССР, 1982. С. 19-32].

Seravkin I.B., Znamensky S.E., Kosarev A.M., 2001. Fault Tectonics and Ore Deposits of the Trans-Uralian Bashkiria. Ufa Poligrafcombinat, Ufa, 318 p. (in Russian) [Серавкин И.Б., Знаменский С.Е., Косарев А.М. Разрывная тектоника и рудоносность Башкирского Зауралья. Уфа: Уфимский полиграфкомбинат, 2001. 318 с.].

Simanenko V.P., Golozubov V.V., Sakhno V.G., 2006. Geochemistry of Volcanic Rocks from Transform Margins: Evidence from the Alchan Basin, Northwestern Primorie. Geochemistry International 44,1157-1169. https://doi.org/ 10.1134/S0016702906120019.

Simonov V.A., Dunaev A.Yu., Kovyazin S.V., Zaikov V.V., 2004. Magmatic Systems of Paleooceans: Data on Melt Inclusions in Chromian Spinels. In: Geodynamic Evolution of the Lithosphere of the Central Asian Mobile Belt (from Ocean to Continent). Proceedings of Scientific Meeting (October 19-22, 2004). Iss. 2. Vol. 2. Publishing House of IEC SB RAS, Irkutsk, p. 97-100 (in Russian) [Симонов В.А., Дунаев А.Ю., Ковязин С.В., Зайков В.В. Магматические системы палеоокеанов: данные по расплавным включениям в хромшпинелидах // Геодинамическая эволюция литосферы Центрально-Азиатского подвижного пояса (от океана к континенту): Материалы научного совещания по Программе фундаментальных исследований ОНЗ РАН (1922 октября 2004 г.). Иркутск: Изд-во ИЗК СО РАН, 2004. Вып. 2. Т. 2. С. 97-100]. 
Snachev V.I., Mavrinskaya T.M., 1995. Some Problems of Poletaevka Ore Field Stratigraphy. In: Yearbook 1994. Publishing House of the Ufa Scientific Centre of RAS, Ufa, p. 3334 (in Russian) [Сначев В.И., Мавринская Т.М. Некоторые проблемы стратиграфии Полетаевской площади // Ежегодник-1994. Уфа: Изд-во УНЦ РАН, 1995. С. 33-34].

Sobolev I.D. (Ed.), 1971. Geological Map of the Urals. Scale 1:1000000. Territorial Geological Fund, Sverdlovsk (in Russian) [Геологическая карта Урала масштаба 1:1000000 / Ред. И.Д. Соболев. Свердловск: ТГФ, 1971].

Sopko P.F., 1969. Tectonic Conditions for the Formation and Placement of Magmatic Formations in the Bashkir Part of the Magnitogorsk Megasynclinorium. Proceedings of Higher Educational Establishments. Geology and Exploration 4, 3-10 (in Russian) [Сопко П.Ф. Тектонические условия формирования и размещения магматических образований в Башкирской части Магнитогорского мегасинклинория // Известия вузов. Геология и разведка. 1969. № 4. С. 3-10].

Sopko P.F., Bobochov A.S., Seravkin I.B., Kosarev A.M., 1983. Middle Paleozoic Volcanism of the Bashkirian TransUral Region and Related Massive Sulfide Mineralization. Publishing House of the Bashkir Branch of the USSR Academy of Sciences, Ufa, 116 p. (in Russian) [Сопко П.Ф., Бобохов А.С., Серавкин И.Б., Косарев А.М. Среднепалеозойский вулканизм Башкирского Зауралья и связь с ним колчеданного оруденения. Уфа: Изд-во БФ АН СССР, 1983. 116 c.].

Spadea P., D’Antonio M., Kosarev A., Gorozhanina Y., Brown D., 2002. Arc-Continent Collision in the Southern Urals: Petrogenetic Aspects of the Forearc-Arc Complex, In: Mountain Building in the Uralides: Pangea to the Present. AGU Geophysical Monograph Series 132, 101-134. https:// doi.org/10.1029/132GM07.

Stratigraphic Schemes of the Urals (Precambrian, and Paleozoic), 1993. Interdepartmental Stratigraphic Committee of Russia, Ekaterinburg, 151 p. (in Russian) [Стратиграфические схемы Урала (докембрий, палеозой). Екатеринбург: Межведомственный стратиграфический комитет России, 1993. 151 с.].

Surin T.N., 1997. Petrological and Mineralogical Studies of Magmatism in the East-Magnitogorsk Belt. Geotur, Miass, 309 p. (in Russian) [Сурин T.Н. Петролого-минералогические исследования магматитов Восточно-Магнитогорского пояса (Южный Урал). Миасс: Геотур, 1997. 310 с.].

Tal'nov E.S., 2003. Evolution of Paleozoic Volcanism and Volcanic Massive Sulfide Mineralization in the South Urals (Case Study of the Dzhusa Island-Arc System). In: Proceedings of the Scientific Research Institute of Geology of the Chernyshevsky Saratov State University. New Series. Vol. XV. Nauchnaya Kniga, Saratov, 175 p. (in Russian) [Тальнов Е.C. Особенности эволюции палеозойского вулканизма и колчеданного оруденения Южного Урала (на примере Джусинской островодужной системы) // Труды НИИГео СГУ им. Н.Г. Чернышевского. Новая серия. Саратов: Научная книга, 2003. T. XV. 175 с.].

Tatsumi Y., Hamilton D.L., Nesbitt R.W., 1986. Chemical Characteristics of Phases Released from a Subducted
Lithosphere and Origin of Arc Magmas: Evidence from HighPressure Experiments and Natural Rocks. Journal of Volcanology and Geothermal Research 29 (1-2), 293-309. https:// doi.org/10.1016/0377-0273(86)90049-1.

Taylor S.R., McLennan S.M., 1985. The Continental Crust: Its Composition and Evolution. Blackwell, Oxford, 379 p.

Teterev G.M. (Ed.), 1971. Geology of the USSR. Vol. 34. Book 2. Nedra, Moscow, 312 p. (in Russian) [Геология СССР / Ред. Г.М. Тетерев. М.: Недра, 1971. Т. 34. Кн. 2. 312 с.].

Tevelev A.V., Kosheleva I.A., 2002. Geology and History of the South Urals (East Ural Uplift and Trans-Urals). MSU Publishing House, Moscow 123 p. (in Russian) [Тевелев A.В., Кошелева И.А. Геологическое строение и история развития Южного Урала (Восточно-Уральское поднятие и Зауралье). М.: Изд-во МГУ, 2002. 123 с.].

Tevelev A.V., Kosheleva I.A., Furina M.A., Belyatsky B.V., 2009. Triassic Magmatism in the South Urals: Geochemistry, Isotope Systematics, Composition, and Geodynamics. Moscow University Geology Bulletin 2, 29-38 (in Russian) [Тевелев А.В., Кошелева И.А., Фурина М.А., Беляцкий Б.В. Триасовый магматизм Южного Урала: геохимия, изотопия, геодинамика // Вестник МГУ. Серия 4. Геология. 2009. № 2. C. 29-38].

Tevelev A.V., Kosheleva I.A., Popov V.S., Kuznetsov I.E., Osipova T.A., Pravikova N.V., Vostretsova E.S., Gustova A.S., 2006. Paleozoids of the Eastern Ural/Trans-Ural Junction. In: A.M. Nikishin (Ed.), Proceedings of the Laboratory of Orogeny. Iss. 4. MSU Publishing House, Moscow, 300 p. (in Russian) [Тевелев А.В., Кошелева И.А., Попов В.С., Кузнецов И.Е., Осипова Т.А., Правикова Н.В., Вострецова Е.С., Густова А.С. Палеозоиды зоны сочленения Восточного Урала и Зауралья // Труды лаборатории геологии складчатых поясов / Ред. А.М. Никишин. М.: Изд-во МГУ, 2006. Вып. 4. 300 с.].

Tishchenko V.T., 1971. Lower Devonian Alkali Basalts in the Southern Part of the Western Magnitogorsk Trough. In: Book of Abstracts of First Symposium on Volcanism of the Southern Urals. Publishing House of the Ufa Scientific Centre of RAS, Miass, 43-44 (in Russian) [Тищенко В.Т. Щелочно-базальтоидная формация нижнего девона в южной части западного крыла Магнитогорского прогиба // Тезисы докладов I симпозиума по вулканизму Южного Урала. Миасс: Изд-во УНЦ РАН, 1971. C. 43-44.].

Tychkov S.A., Vladimirov A.G., 1997. Model of Break-Off of the Subducted Oceanic Lithosphere in the Indo-Eurasian Collision Zone. Doklady Earth Sciences 354 (4), 515-518.

Vladimirov A.G., Fan L.A., Travin A.V., Micheev E.I., Murzitsev N.G., Annikova I.Y., 2020. Geology and Thermochronology of Cretaceuos Magmatism of Southeastern Vietnam. Russian Journal of Pacific Geology 14, 305-325. https:// doi.org/10.1134/S1819714020040065.

Volynets O.N., Antipin V.S., Perepelov A.B., Anoshin G.N., 1990. Geochemistry of Volcanic Series of Island Arc Systems Applied to Geodynamics (Kamchatka). Russian Geology and Geophysics 5, 3-13 (in Russian) [Волынец 0.Н., Антипин В.С., Перепелов А.Б., Аношин Г.Н. Геохимия вулканических серий островодужной системы в приложении 
к геодинамике (Камчатка) // Геология и геофизика. 1990. № 5. C. 3-13].

Winchester J.A., Floyd P.A., 1977. Geochemical Discrimination of Different Magma Series and Their Differentiation Products Using Immobile Elements. Chemical Geology 20, 325-343. http://dx.doi.org/10.1016/0009-2541(77) 90057-2.

Yazeva R.G., Bochkarev V.V., 1998. Geology and Geodynamics of the South Urals (Experience of Geodynamic Mapping). Publishing House of the Ural Branch of RAS, Ekaterinburg, 203 p. (in Russian) [Язева Р.Г., Бочкарев В.В. Геология и геодинамика Южного Урала (опыт геодинамического картирования). Екатеринбург: УрО РАН, 1998. 203 c.].

Zaykov V.V., Maslennikov V.V., Zaykova E.V., Herrington R., 2001. Ore-Formation and Ore-Facial Analysis of Base Metal Massive Sulphide Deposits of the Urals Paleoocean. Publishing House of the Institute of Mineralogy UB RAS, Miass, 315 p. (in Russian) [Зайков В.В., Масленников В.В., Зайкова Е.В., Херрингтон Р. Рудно-формационный и рудно-фациальный анализ колчеданных месторождений Уральского палеоокеана. Миасс: Изд-во ИМин УрО РАН, 2001. 315 c.].
Zaykov V.V., Melekestseva I.Yu., Artem'ev D.A., Simonov V.A., Yuminov A.M., Dunaev A.Yu., 2009. Geology and Massive Sulphide Mineralization of the Southern Flank of the Main Ural Fault. Publishing House of the Institute of Mineralogy UB RAS, Miass, 375 p. (in Russian) [Зайков B.В., Мелекесцева И.Ю., Артемьев Д.А., Юминов А.М., Симонов В.А., Дунаев А.Ю. Геология и колчеданное оруденение южного фланга Главного Уральского разлома. Миасс: Изд-во ИМин УрО РАН, 2009. 375 с.].

Znamensky S.E., 2009. Structural Conditions of Formation of Collision Gold Deposits of the Eastern Slope of the Southern Urals. Gilem, Ufa, 345 p. (in Russian) [Знаменский C.E. Структурные условия формирования коллизионных месторождений золота восточного склона Южного Урала. Уфа: Гилем, 2009. 345 с.].

Zoloev K.K., Volchenko Yu.A., Koroteev V.A., Malakhov I.A, Mardirosyan A.N., Hrypov V.N., 2001. Platinum Mineralization in Geological Complexes of the Urals. Publishing House of the Ural Branch of RAS, Ekaterinburg, 198 p. (in Russian) [Золоев К.К., Волченко Ю.А., Коротеев В.А., Малахов И.А., Мардиросьян А.Н., Хрыпов В.Н. Платинометалльное оруденение в геологических комплексах Урала. Екатеринбург: Изд-во УрО РАН, 2001. 199 с.]. 